\title{
Late Holocene evolution of a coupled, mud-dominated delta plain-chenier plain system, coastal Louisiana, USA
}

\author{
Marc P. Hijma ${ }^{1,2}$, Zhixiong Shen ${ }^{1,3}$, Torbjörn E. Törnqvist ${ }^{1}$, and Barbara Mauz ${ }^{4}$ \\ ${ }^{1}$ Department of Earth and Environmental Sciences, Tulane University, \\ 6823 St. Charles Avenue, New Orleans, Louisiana 70118-5698, USA \\ ${ }^{2}$ Department of Applied Geology and Geophysics, Deltares, P.O. Box 85467, 3508 AL Utrecht, the Netherlands \\ ${ }^{3}$ Department of Marine Science, Coastal Carolina University, \\ P.O. Box 261954, Conway, South Carolina 29528, USA \\ ${ }^{4}$ Department of Geography and Planning, University of Liverpool, Liverpool L69 7ZT, UK
}

Correspondence to: Marc P. Hijma (marc.hijma@deltares.nl)

Received: 24 April 2017 - Discussion started: 4 May 2017

Revised: 12 September 2017 - Accepted: 25 September 2017 - Published: 2 November 2017

\begin{abstract}
Major deltas and their adjacent coastal plains are commonly linked by means of coast-parallel fluxes of water, sediment, and nutrients. Observations of the evolution of these interlinked systems over centennial to millennial timescales are essential to understand the interaction between point sources of sediment discharge (i.e. deltaic distributaries) and adjacent coastal plains across large spatial (i.e. hundreds of kilometres) scales. This information is needed to constrain future generations of numerical models to predict coastal evolution in relation to climate change and other human activities. Here we examine the coastal plain (Chenier Plain, CP) adjacent to the Mississippi River delta, one of the world's largest deltas. We use a refined chronology based on 22 new optically stimulated luminescence and 22 new radiocarbon ages to test the hypothesis that cyclic Mississippi subdelta shifting has influenced the evolution of the adjacent CP. We show that over the past $3 \mathrm{kyr}$, accumulation rates in the $\mathrm{CP}$ were generally $0-1 \mathrm{Mt} \mathrm{yr}^{-1}$. However, between 1.2 and $0.5 \mathrm{ka}$, when the Mississippi River shifted to a position more proximal to the $\mathrm{CP}$, these rates increased to $2.9 \pm 1.1 \mathrm{Mt} \mathrm{yr}^{-1}$ or $0.5-1.5 \%$ of the total sediment load of the Mississippi River. We conclude that CP evolution during the past $3 \mathrm{kyr}$ was partly a direct consequence of shifting subdeltas, in addition to changing regional sediment sources and modest rates of relative sea-level (RSL) rise. The RSL history of the CP during this time period was constrained by new limiting data points from the base of overwash deposits associated with the cheniers.

These findings have implications for Mississippi River sediment diversions that are currently being planned to restore portions of this vulnerable coast. Only if such diversions are located in the western portion of the Mississippi Delta plain could they potentially contribute to sustaining the CP shoreline. Our findings highlight the importance of a better understanding of mud-dominated shorelines that are often associated with major deltas, in light of the enormous investments in coastal management and restoration that will likely be made around the globe, now and especially later during this century.
\end{abstract}




\section{Introduction}

Low-elevation coastal zones are facing severe pressures due to a combination of rapid coastal development (e.g. McGranahan et al., 2007), the effects of accelerated relative sea-level (RSL) rise (e.g. Ericson et al., 2006), and sediment deficits (e.g. Syvitski et al., 2005). The steadily increasing proportion of the world population in coastal lowlands has become one of the most pressing global environmental problems within the context of climate change (Wong et al., 2014). This is particularly the case for major deltas and their adjacent coastal plains that are linked by means of coastparallel fluxes of water, sediment, and nutrients. Mud constitutes a dominant component of this material flux as exemplified by some of the world's largest sediment-delivery systems (e.g. Saito et al., 2000; Anthony et al., 2013; Szczuciński et al., 2013), yet surprisingly few studies have focused on the large-scale evolution of mud-dominated shorelines.

Observations over centennial to millennial timescales are particularly useful to understand the interaction between point sources of sediment discharge (i.e. deltaic distributaries) and adjacent coastal plains across large spatial (i.e. hundreds of kilometres) scales. The Holocene stratigraphic record contains a potentially powerful but underutilized archive for this purpose. In addition to increasing our understanding of large-scale coastal morphodynamics, information from the Holocene record is essential to constrain future generations of numerical models that will be needed to enable predictions about coastal evolution (e.g. Allison and Meselhe, 2010; Paola et al., 2011). Such models can be expected to become increasingly important in view of the enormous investments in coastal management and restoration that will likely be made around the globe.

The Mississippi River has constructed one of the world's largest delta plains (the Mississippi Delta plain, MDP) during the Holocene. The MDP is presently dissected by two major distributaries (the Mississippi River and the Atchafalaya River) which feed active parts of the delta referred to herein as subdeltas (cf. Russell, 1940). In the past, the Mississippi River has shifted its course periodically as is evident from abandoned (inactive) subdeltas (Fig. 1). The associated redistribution of sediment along the coast resulted in "healing" of scars in the coastline. Currently, the distributaries are completely embanked, resulting in large, sediment-starved sections that subside and erode rapidly. Coastal Louisiana experiences among the world's highest rates of wetland loss, with rates of $30-50 \mathrm{~km}^{2} \mathrm{yr}^{-1}$ in the last two decades (Couvillion et al., 2017). This coastal degradation could be mitigated by artificially diverting sediment from the river back to the MDP (e.g. Day et al., 2007), which could potentially also influence the evolution of the Chenier Plain (CP), farther to the west (Fig. 1). The CP is a $250 \mathrm{~km}$ long and $20-40 \mathrm{~km}$ wide lowlying marsh area with interspersed sandy ridges (cheniers). It has been proposed that during the past three millennia (Gould and McFarlan, 1959), several cycles of Mississippi subdelta shifting resulted in the formation of alternating cheniers and mudflats (Russell and Howe, 1935; McBride et al., 2007). The hypothesis is that when the mouth of the Mississippi River is situated close to the CP, large amounts of muddy sediment are transported towards the $\mathrm{CP}$ via the east to west longshore current. When the river mouth shifts to a more easterly position, mud delivery is reduced and waves can attack and rework the mudflats, hereby forming the cheniers (Russell and Howe, 1935). To test this hypothesis it is essential to have proper time control for the active period of past subdeltas as well as for the formation of the cheniers. At present, this time control is still largely based on research and radiocarbon ages from the 1950s-1960s (Gould and McFarlan, 1959; McFarlan, 1961; Saucier, 1963; Frazier, 1967). The chronology of the cheniers is based on reworked shells that could predate the cheniers considerably (e.g. Shang et al., 2016). Over the past half century, the accuracy of radiocarbon dating and sampling strategies has increased significantly. For instance, re-examining one of the shifts of the Mississippi River (Törnqvist et al., 1996) resulted in an age that differed up to 2000 radiocarbon years from previously established ages. A major step forward in the last few decades is the possibility to directly determine the age of deposition of clastic sediments using optically stimulated luminescence (OSL). In recent years this method has been successfully applied to date sand and very fine silt from MDP sediments (Shen and Mauz, 2012; Shen et al., 2015, 2017).

Here we present new chronological data for both the CP and the MDP to more rigorously test the hypothesis that their evolution was interlinked. We also examine the relationship between chenier formation and late Holocene RSL rise, using the base of overwash deposit associated with cheniers as an indicator of the upper limit of contemporaneous sea level. This information is important because cheniers mark palaeo-shorelines, and hence any past RSL changes could also have influenced $\mathrm{CP}$ evolution. To date the sandy cheniers, we used OSL measurements to establish their period of formation. In the MDP we used radiocarbon and OSL dating to refine the existing chronology. We traced six major chenier palaeo-shorelines and calculated the area and mass of the interspersed mudflats to estimate minimum sediment accumulation rates through time. We aimed to determine to what extent the evolution of the $\mathrm{CP}$ is linked to subdelta shifting in the MDP, including the possible implications for coastal restoration plans, both in Louisiana and elsewhere in the world.

\section{Regional setting and previous research}

\subsection{Chenier Plain}

The northern border of the CP is formed by the outcropping Prairie Allogroup (Heinrich, 2006) that dips towards the south and is onlapped by Holocene strata (Fig. S1 in the Sup- 

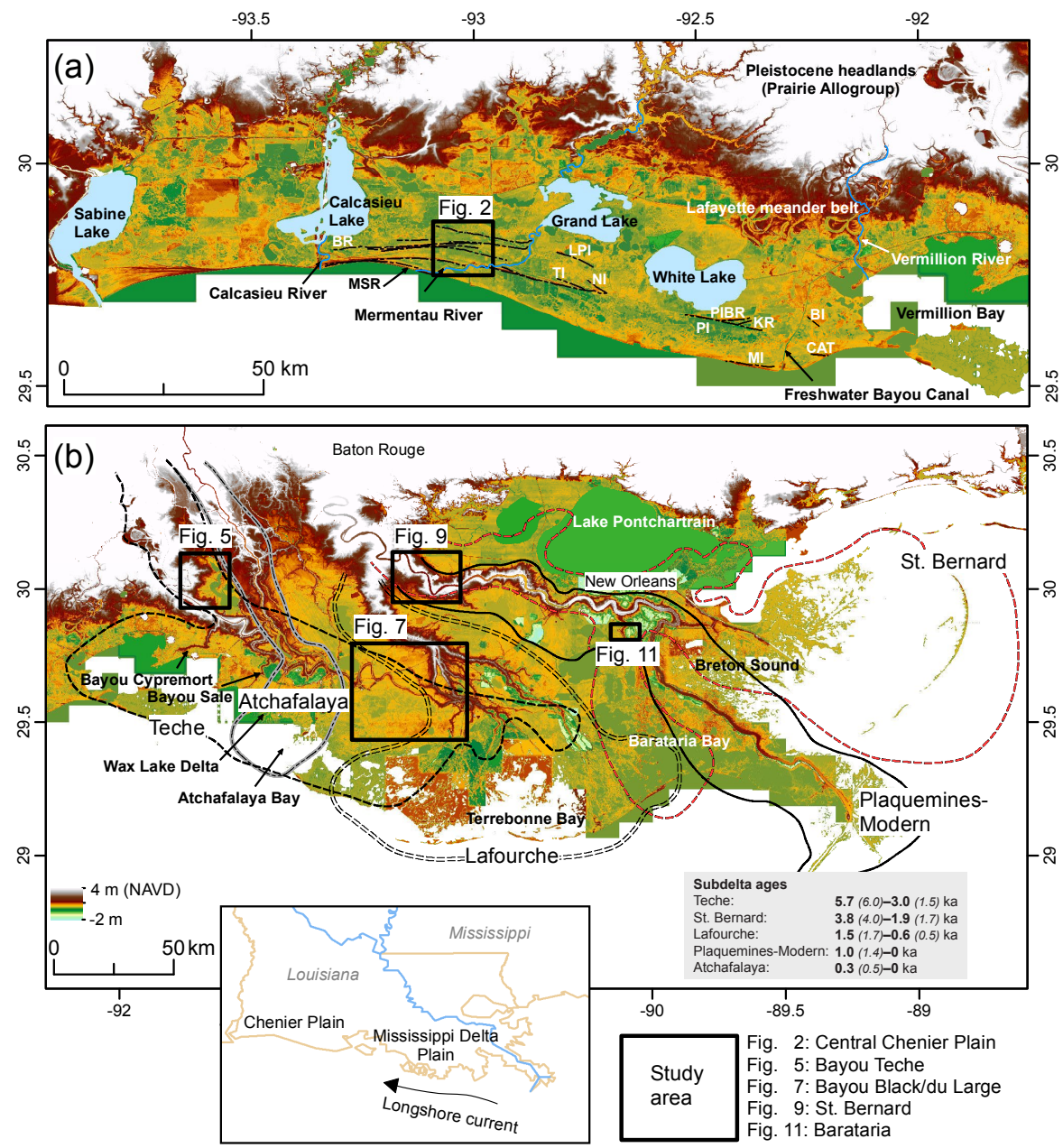

Figure 1. Digital elevation maps (NED 1/1 arcsec; Gesch, 2007; LSU, 2011) of the study areas, including (a) the Chenier Plain with the main cheniers indicated by the black lines and (b) the Mississippi Delta plain with the position of its subdeltas. The outline of the subdeltas is essentially the same as in Frazier (1967), but in line with Fisk (1944) the Teche subdelta extends farther east. BR: Back Ridge; MSR: Mesquitte Ridge; TI: Tiger Island; LPI: Little Pecan Island; NI: North Island; PI(BR): Pecan Island (Back Ridge); MI: Mulberry Island; KR: Kochs Ridge; BI: Belle Island; CAT: Chenier au Tigre. In the box with subdelta ages the bold numbers indicate the period of activity, while the smaller numbers in italics reflect the possible period of activity (see also Fig. 14).

plement). The Pleistocene headlands reach farthest south at the location of the Lafayette meander belt (Fig. 1a) that was dated to Marine Isotope Stage 5a (Shen et al., 2012). The $\mathrm{CP}$ consists of widespread marshes with interspersed ridges that constitute the only dry, habitable areas. They are oriented roughly parallel to the current shoreline, have mean elevations of 1-2 m NAVD 88 (all elevations in this paper are with respect to the North American Vertical Datum (NAVD) of 1988 , roughly equivalent to present-day mean sea level) and can have lengths of tens of kilometres. The width of the ridges varies considerably due to overwash deposits and the presence of merging ridges, but is $\sim 200 \mathrm{~m}$ on average. Most of the ridges are cheniers, meaning that they are "beach ridges, resting on silty or clayey deposits, which become isolated from the shore by a band of tidal mudflats" (Otvos and
Price, 1979) and "flanked by intervening and usually wider intertidal-subtidal flats" (Otvos, 2000). Cheniers form when progradation is interrupted by a phase of erosion and transgression and mainly consist of (very) fine sand and shells due to winnowing processes. Once formed, they usually migrate landward due to washover process until the crest becomes high enough to withstand the highest spring tides (Augustinus, 1989). From that point on they are rather stable, accretionary features that sometimes start to prograde seaward (Gould and McFarlan, 1959) and become regressive cheniers (cf. Otvos, 2000). Our study focuses on the central part of the CP (Fig. 1a) as it contains the most complete series of cheniers. In addition to cheniers, some ridges in the $\mathrm{CP}$, especially around river mouths, started as spits and built out laterally as curved beach ridges (Gould and McFarlan, 


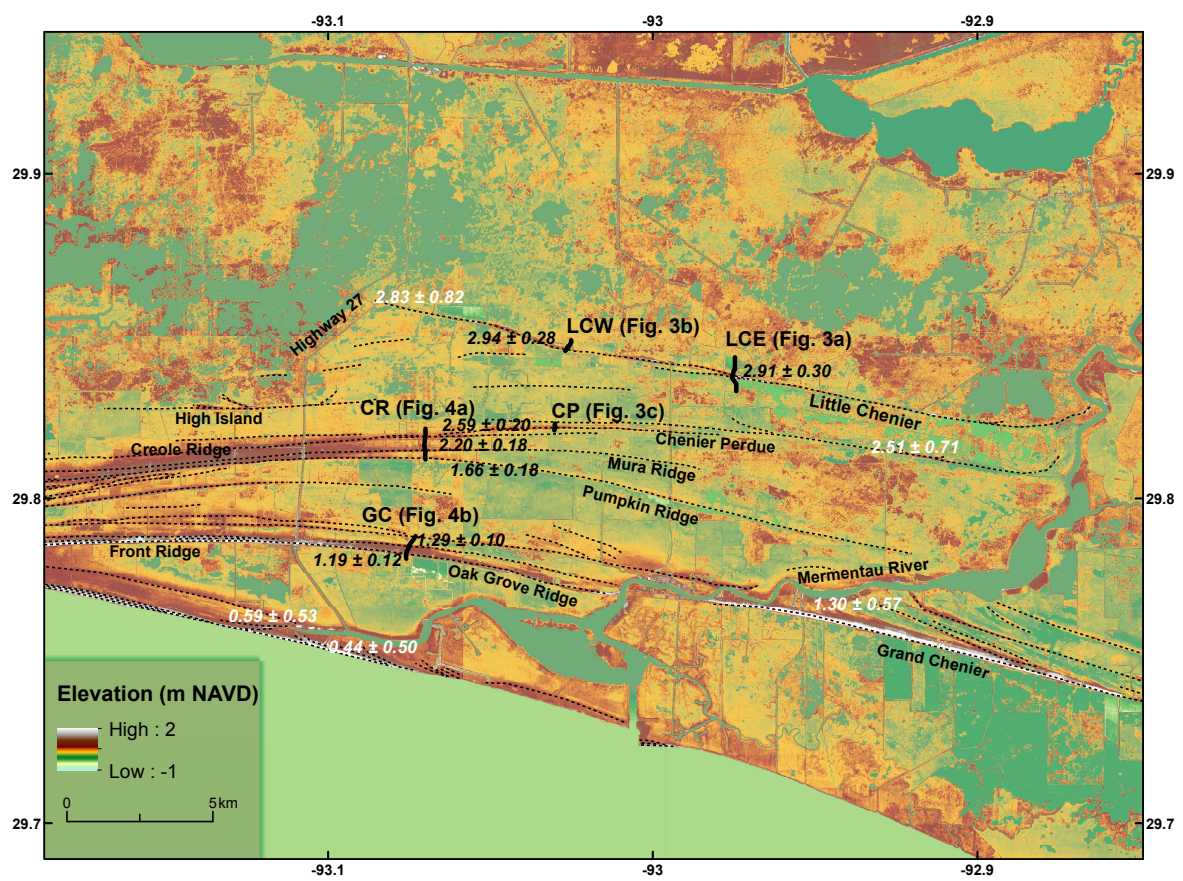

Figure 2. Digital elevation map (NED 1/3 arcsec) of the Chenier Plain study area (for location see Fig. 1a) with the location of the different cross sections: Little Chenier East (LCE), Little Chenier West (LCW), Chenier Perdue (CP), Creole Ridge (CR, consisting of Chenier Perdue, Mura Ridge and Pumpkin Ridge) and Grand Chenier/Oak Grove Ridge (GC). The OSL ages (Table 1) are shown in black, selected radiocarbon ages from Gould and McFarlan (1959) are in white (Table S1). The OSL ages and the calibrated radiocarbon ages are expressed in $\mathrm{ka}( \pm 2 \sigma)$ with respect to AD 2010. The dotted lines indicate the position of cheniers.

1959; Penland and Suter, 1989; McBride et al., 2007). The dominant onshore wave approach is from the southeast, resulting in a longshore current to the west (Fig. 1), although ridge morphology near river mouths show clear signs of local reversal due to ebb-tidal estuarine interactions (McBride et al., 2007). Four small rivers dissect the CP (Rosen and Xu, 2011): Sabine River (average discharge of $219 \mathrm{~m}^{3} \mathrm{~s}^{-1}$ ), Calcasieu River $\left(72 \mathrm{~m}^{3} \mathrm{~s}^{-1}\right)$, Mermenteau River $\left(82 \mathrm{~m}^{3} \mathrm{~s}^{-1}\right)$ and Vermillion River $\left(33 \mathrm{~m}^{3} \mathrm{~s}^{-1}\right)$. The mean tidal range is on the order of $0.3-0.4 \mathrm{~m}$ and is unlikely to have seen much change over the time window of interest to the present study (Hill et al., 2011).

The first and still the most extensive set of cross sections across the CP was presented by Fisk (1948), with considerable detail added by Byrne et al. (1959). Together with Gould and McFarlan (1959), who used extensive radiocarbon dating (Table S1 in the Supplement) to reconstruct the geological history, these papers still form the nucleus for our understanding of $\mathrm{CP}$ evolution. Above the Pleistocene substrate, Gould and McFarlan (1959) recognized a transgressive sequence extending all the way to the Pleistocene outcrops north of the CP (Fig. S1). Penland and Suter (1989) noted that the absence of clear shoreline features along the Pleistocene outcrop and the presence of thick marsh deposits between the Pleistocene outcrop and the most landward cheniers make it unlikely that the shoreline ever reached the out- crop itself. The cheniers contain numerous shells or shell fragments, sometimes concentrated in shell hash. The seaward front of the cheniers is relatively steep (3-7\%), while the landward side is gentle, grades into the marsh and was formed during overwash events. Combining maps and radiocarbon dating (Table S1), Gould and McFarlan (1959) identified several palaeo-shorelines of which the Little Chenier, Creole-Pumpkin Ridge, Oak Grove-Grand Chenier and the chenier near the present shoreline are the most prominent (Fig. 2). They concluded that the CP formed during the past $\sim 3 \mathrm{kyr}$ as a result of net progradation. Yu et al. (2012) showed that RSL in the CP was about $1.5 \mathrm{~m}$ below present mean sea level around $3 \mathrm{ka}$, thus challenging the hypothesis (Penland and Suter, 1989; McBride et al., 2007) that RSL fall was one of the drivers of $\mathrm{CP}$ progradation.

\subsection{Mississippi Delta plain}

Mississippi subdelta shifting during the Holocene has been studied intensively during the last century, resulting in a robust stratigraphic framework (see Coleman et al., 1998, and Blum and Roberts, 2012, for reviews of this topic). The five most recent subdeltas (Teche, St. Bernard, Lafourche, Plaquemines-Modern, Atchafalaya; Fig. 1b) formed during a period of continuous RSL rise (González and Törnqvist, 2009; Yu et al., 2012). They are generally well preserved 
and hence mapping has been reasonably straightforward (e.g. Roberts and Coleman, 1996). The chronology of these subdeltas is still largely based on work from the 1960s (McFarlan, 1961; Saucier, 1963; Frazier, 1967), although later work has led to significant revisions (Penland et al., 1987; Autin et al., 1991; Törnqvist et al., 1996). The subdeltas generally formed in less than $10 \mathrm{~m}$ deep water, with the exception of the currently active Plaquemines-Modern subdelta that has prograded into relatively deep water $(>50 \mathrm{~m})$; its mouth is situated close to the shelf edge (Fisk et al., 1954). The combined sediment delivery to the Gulf of Mexico by the Mississippi and Atchafalaya rivers is presently about $175 \mathrm{Mtyr}^{-1}$ (Meade and Moody, 2010). This is considerably lower than the $400-500 \mathrm{Mt} \mathrm{yr}^{-1}$ right before upstream parts of the Mississippi River were dammed, as well as the estimated average of $230-290 \mathrm{Mt} \mathrm{yr}^{-1}$ for the past $12 \mathrm{kyr}$ (Blum and Roberts, 2009). For our calculations, we assume that the total sediment load of the Mississippi River during $\mathrm{CP}$ evolution was somewhere between 200 and $400 \mathrm{Mtyr}^{-1}$. As in the $\mathrm{CP}$, the mean tidal range along the MDP is $0.3-0.4 \mathrm{~m}$.

\subsection{Conceptual models of interlinked Chenier Plain and Mississippi Delta plain evolution}

Mississippi River mud is transported westward by the longshore current and forms a blanket on the shelf. Mudflat accretion on the $\mathrm{CP}$ is linked to high-energy events (cold front passages, storms) when the mud is transported onshore (Roberts et al., 1989; Draut et al., 2005a). It has long been assumed (Howe et al., 1935; Russell and Howe, 1935) that when the western part of the MDP (within $\sim 100 \mathrm{~km}$ from the CP) is active, more mud can reach the $\mathrm{CP}$ than when the eastern part is active (the present Mississippi River mouth is located $\sim 350 \mathrm{~km}$ from the $\mathrm{CP}$ ). Similar inferences have been made for other major delta regions that host cheniers (Saito et al., 2000; Anthony et al., 2013). Recent mudflat accretion immediately west of the Atchafalaya River mouth exemplifies that parts of the river output end up in the CP (Draut et al., 2005b). Gould and McFarlan (1959), however, have already indicated that this relationship is not straightforward and described periods with simultaneous mudflat accumulation and chenier formation in different portions of the CP. Likewise, McBride et al. (2007) reported the simultaneous growth of transgressive, regressive and laterally accreted ridges. They agreed in general with the model proposed in the 1930s, but showed that during the transgressive phase of chenier formation, regressive ridges can form near stable river outlets and laterally accreted ridges near unstable outlets.

The two most recent papers addressing the CP-MDP link (Penland and Suter, 1989; McBride et al., 2007) correlate $\mathrm{CP}$ erosion/progradation patterns to bifurcations within the Lafourche subdelta. In addition to changes in the MDP, McBride et al. (2007) suggest that the formation of the Little Chenier and the Grand Chenier palaeo-shorelines is linked to periods of higher than present-day sea levels. Other po- tential factors influencing chenier formation are storm frequency, wave and tidal regime changes, and bay geometry (Augustinus, 1989). This shows that when studying the sensitivity of the CP to changes in the MDP, the influence of these changes has to be separated from more local influences on $\mathrm{CP}$ formation. At present, progress on this problem is held back by the lack of robust chronologies.

\section{Materials and methods}

\subsection{Stratigraphy and sampling}

Five clearly defined and widely spaced cheniers just west of the Mermentau River were studied (Fig. 2): Oak Grove Ridge, Pumpkin Ridge, Mura Ridge, Chenier Perdue and Little Chenier. We cored several cross sections to understand the local stratigraphy (Figs. 3 and 4) using an Edelman auger and a $1 \mathrm{~m}$ long gouge with $3 \mathrm{~cm}$ diameter. All the sediments were described in the field according to the US Department of Agriculture texture classification system. We classified the depositional environment either as chenier or as non-chenier. The cheniers were labelled as such based on their geomorphological expression, their stratigraphic position above finegrained sediments and their sedimentological characteristics (sand and shells). Our deepest boreholes reach the Pleistocene substrate that is very stiff and mottled and hence easily recognizable. The most sandy and homogenous parts of the cheniers, mostly in the centre, were chosen for OSL sampling. The $2 \sigma$-error range of the OSL ages is on the order of 200-600 years, and since the active period of cheniers is relatively short, this range likely covers the period of existence of the cheniers. Hence, we assume that the OSL ages are representative of the period of formation of the cheniers.

For OSL sampling, we first drilled with the Edelman auger to right above the targeted level and then attached an Eijkelkamp liner sampler, a $30 \mathrm{~cm}$ long and $5 \mathrm{~cm}$ wide metal cylinder with a plastic liner, to the extension rods. This cylinder was then hammered into the ground. Once lifted and detached, the liner sampler was extruded within a light-tight, black plastic bag. Surface elevations were obtained using DEM data (Gesch, 2007; LSU, 2011) with a vertical accuracy of about $0.25 \mathrm{~m}$. DEM data were also used to plot the land surface in the cross sections. The geographical position of borehole sites was determined using a handheld GPS (accuracy $5-10 \mathrm{~m}$ ).

To improve the chronology of the MDP we focused on constraining periods of activity of the trunk channels that feed the Teche, St. Bernard and Plaquemines-Modern subdeltas, but we also dated some smaller distributaries that occur within these subdeltas. Using the same equipment as in the $\mathrm{CP}$, multiple cross sections were again constructed before sampling. Depending on the proximity to the main channel, they exhibit a sandy channel belt with adjacent natural-levee deposits consisting of silt loam and silty clay loam. Moving further into the flood basin, silty clay and clay become dom- 

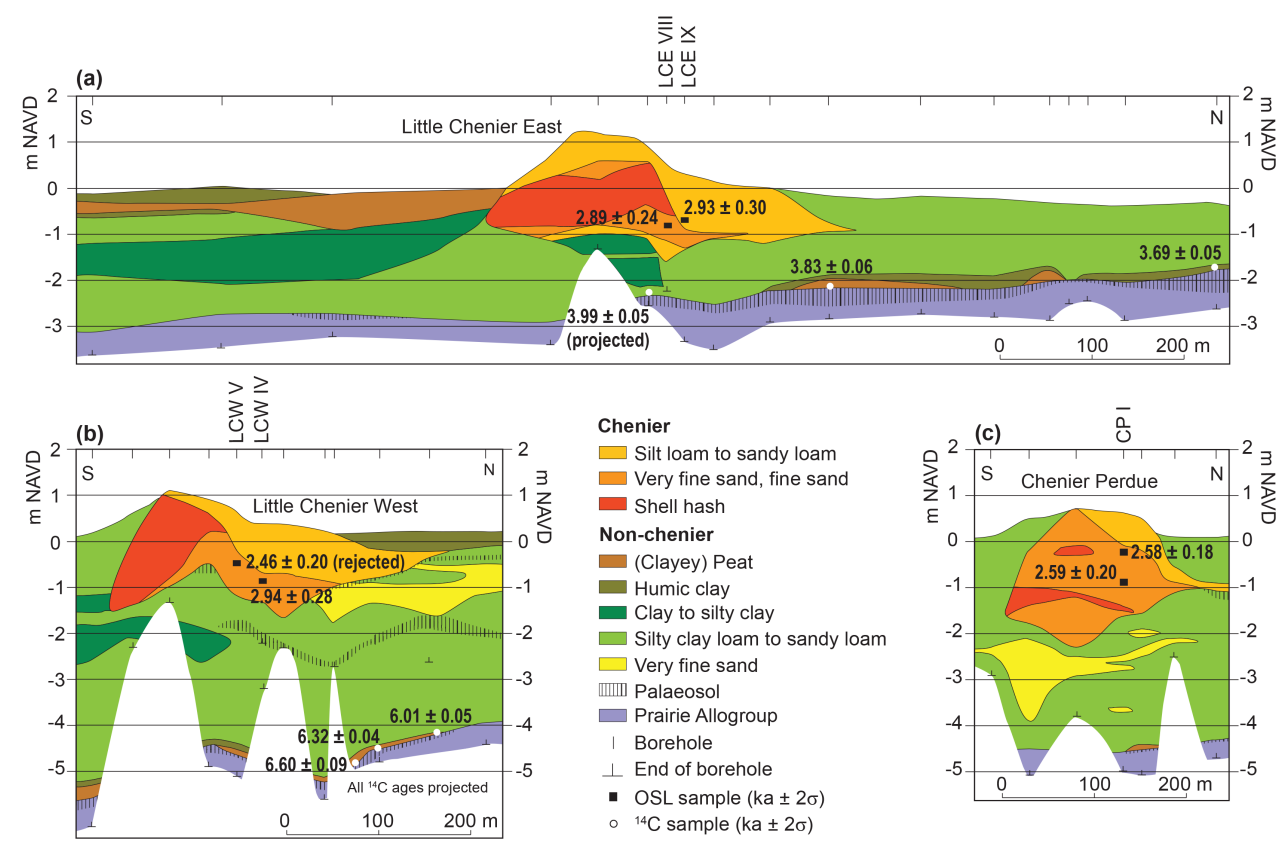

Chenier

$\square$ Silt loam to sandy loam

$\square$ Very fine sand, fine sand

- Shell hash

Non-chenier

(Clayey) Peat

- Humic clay

- Clay to silty clay

$\square$ Silty clay loam to sandy loam

$\square$ Very fine sand

IIIII) Palaeosol

- Prairie Allogroup

I Borehole

$\perp$ End of borehole

- OSL sample $(\mathrm{ka} \pm 2 \sigma)$

- ${ }^{14} \mathrm{C}$ sample $(\mathrm{ka} \pm 2 \sigma)$

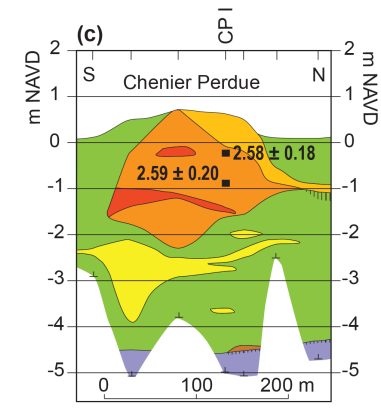

Figure 3. Cross sections across (a) Little Chenier East, (b) Little Chenier West and (c) Chenier Perdue with the stratigraphic position of the OSL samples (Table 1). For location of cross sections see Fig. 2. The radiocarbon ages are from Yu et al. (2012).
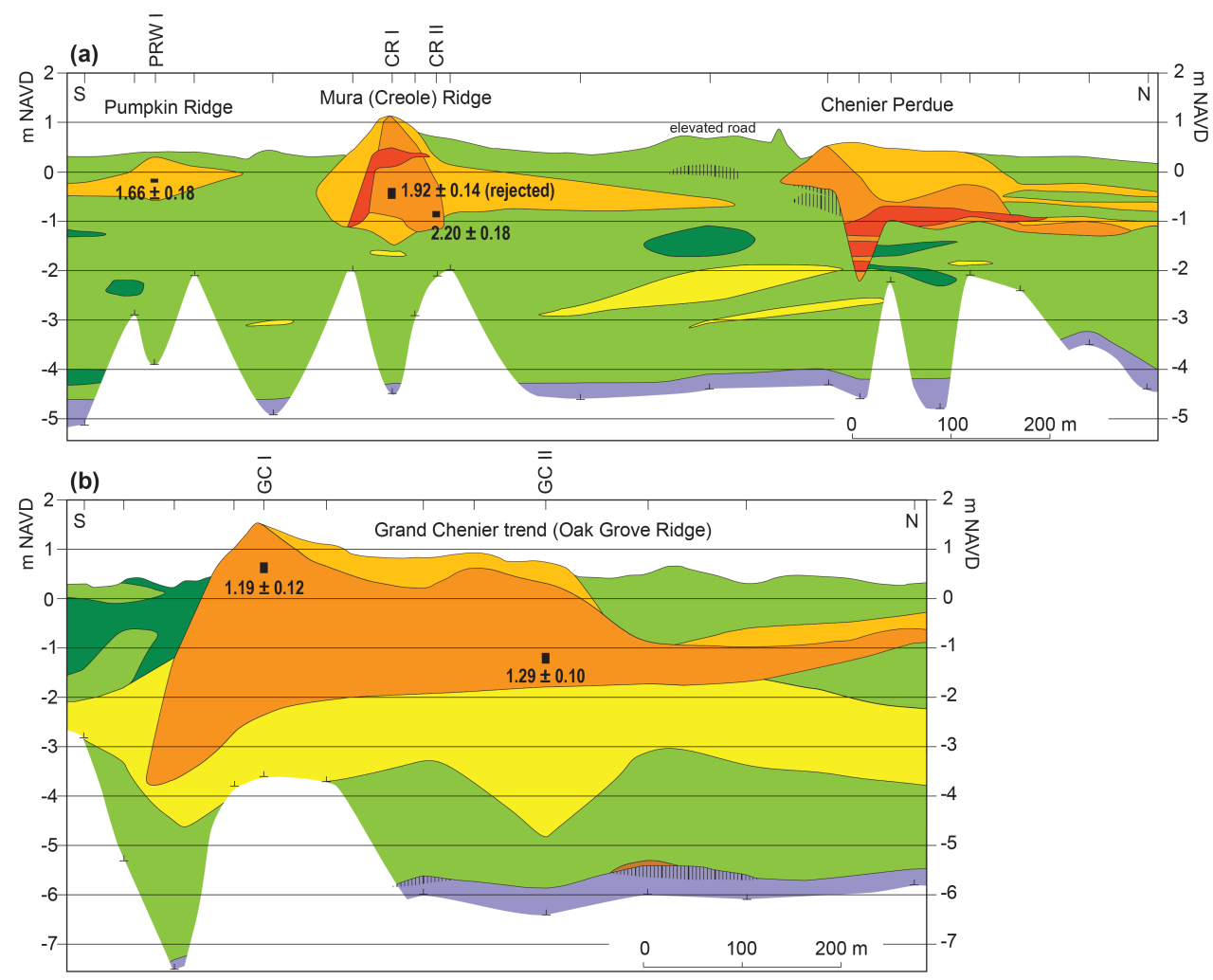

Figure 4. Cross sections across (a) Chenier Perdue-Creole Ridge-Pumpkin Ridge and (b) Grand Chenier (Oak Grove Ridge) with the stratigraphic position of the OSL samples (Table 1). For location of cross sections see Fig. 2; see Fig. 3 for legend. 


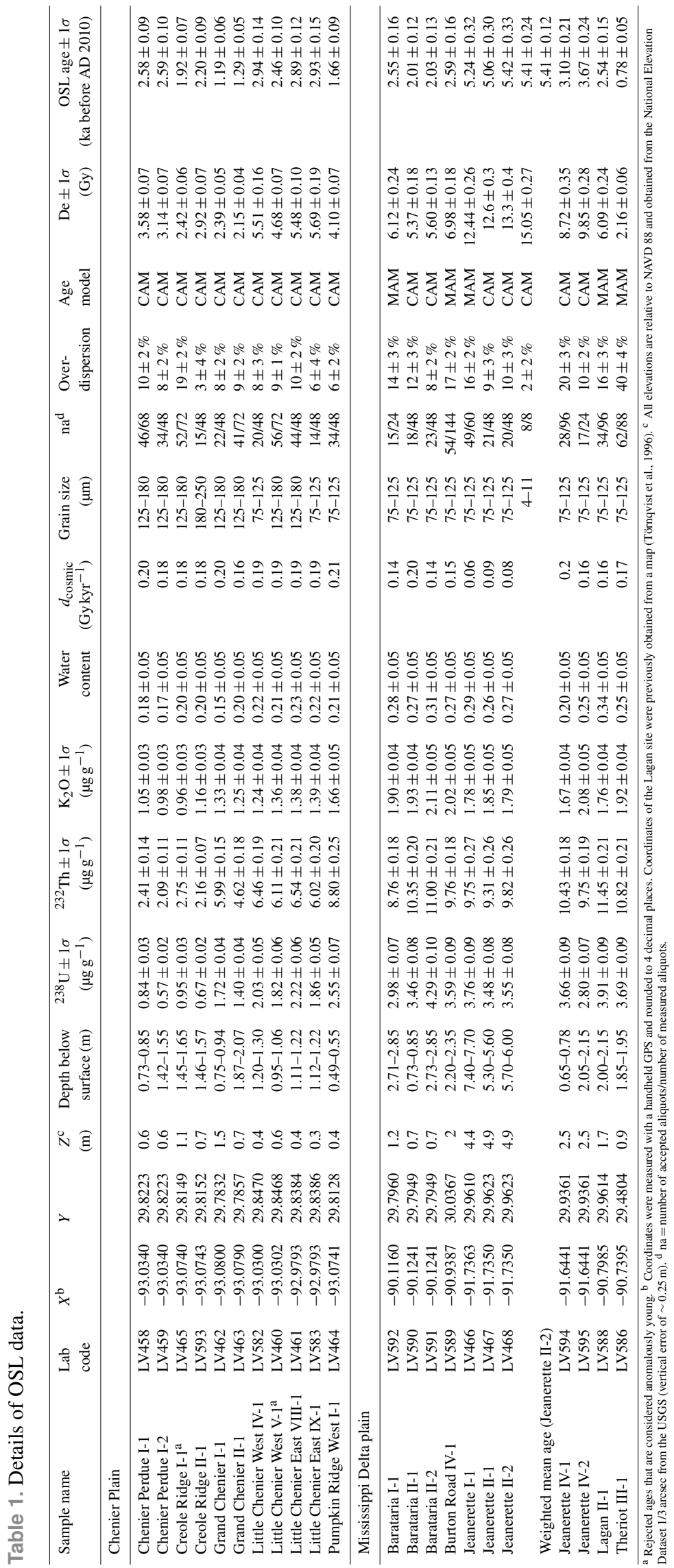


inant and humic clay layers occur frequently. In most cases a peat bed occurs below the overbank deposits, although below the proximal natural-levee deposits peat is often eroded. Sometimes the overbank deposits are covered by a palaeosol that gives way to a peat bed in the flood basin. The beginning of subdelta activity was dated by sampling the top of peat beds below the overbank deposits of the trunk channel, whereas the end of activity was constrained by dating the base of peat beds overlying the overbank deposits. The radiocarbon samples were taken with a $6 \mathrm{~cm}$ wide gouge. As significant amounts of time can elapse before peat starts to form after channel abandonment (Törnqvist and Van Dijk, 1993), we also dated the top of natural-levee deposits using OSL to better constrain the period of activity.

\subsection{Dating}

\subsubsection{OSL dating}

Quartz OSL dating is a dosimetric technique that typically measures the time when quartz was last exposed to sunlight (Aitken, 1998) and has an upper age limit of about $200 \mathrm{ka}$ (Rhodes, 2011). Therefore, it is very useful for dating clastic deposits that lack suitable organic material for radiocarbon dating or are too old to be radiocarbon dated. The $30 \mathrm{~cm}$ long OSL samples were inspected under subdued amber light to select the most homogenous section for dating. The outer rim ( $\sim 1 \mathrm{~cm}$ in thickness) and two ends (1-2 cm in length) of selected core sections were cut off and used for water content and dose rate measurements; remaining sediments were processed following conventional procedures (Mauz et al., 2002) to extract quartz in particle-size ranges of either 4-11, 75-125, 125-180 or $180-250 \mu \mathrm{m}$ for equivalent dose $\left(D_{\mathrm{e}}\right)$ measurement (see also the Supplement). The natural radioactivity of the samples was obtained using a highresolution, low-level gamma-spectrometer at Tulane University and converted to natural dose rates using conversion factors of Adamiec and Aitken (1998), while the contribution of cosmic radiation was calculated using the formula of Prescott and Hutton (1994). The water content during deposition is assumed to be the same as the measured water content. The uncertainty of OSL ages is $3-8 \%$ at the $1 \sigma$ level and was calculated following standard error propagation with uncertainty of the corresponding $D_{\mathrm{e}}(2-4 \%$ at $1 \sigma)$ and the natural dose rate $(3-8 \%$ at $1 \sigma)$ (Table 1$)$. Thus, the variability of OSL age uncertainty is primarily driven by natural dose rate variability. OSL ages in Table 1 are reported in $\mathrm{ka} \pm 1 \sigma$ with respect to AD 2010. To facilitate comparison with the radiocarbon ages, the OSL in the text and figures are reported in $\mathrm{ka} \pm 2 \sigma$.

The most important requirement for OSL dating is complete bleaching of quartz OSL during the latest sunlight exposure. Water-lain deposits, such as the deltaic and beach deposits used in this study, may not always be completely bleached because of attenuation of the sunlight spectrum and intensity by turbid water and transport-mode-dependent exposure time. Identifying completely bleached deposit relies on (1) using small aliquot or single-grain OSL measurements and (2) using appropriate statistical metrics. In this study, small aliquot measurements were done by mounting sand-sized quartz onto the centre 1 to $2 \mathrm{~mm}$ diameter area of $10 \mathrm{~mm}$ diameter stainless-steel disks. The overdispersion parameter (Galbraith et al., 1999) and dose distribution were used collectively to detect insufficient bleaching. The statistical procedure of Arnold et al. (2007) was used to select either a central age model (CAM) or a minimum age model (MAM; see Galbraith et al., 1999) for age calculation of sand-sized quartz samples. A $10 \%$ overdispersion was added in quadrature to the measured $D_{\mathrm{e}}$ error for all aliquots.

Other factors affecting the accuracy of OSL dating include secular disequilibrium in the uranium decay chain and water content variability of the deposit. Recent OSL dating did not find significant secular disequilibrium in MDP deposits (Shen and Mauz, 2012; Shen et al., 2015, 2017). The CP samples probably experienced loss of ${ }^{222} \mathrm{Rn}$ as evidenced by a moderate (generally $<50 \%$ ) deficit of ${ }^{210} \mathrm{~Pb}$ relative to ${ }^{226} \mathrm{Ra}$, but this should not significantly affect the OSL ages (cf. Olley et al., 1996). All OSL samples in this study were taken from near or below the groundwater table. The water content of the $\mathrm{CP}$ samples falls between 15 and $25 \%$ and shows no dependence on sample depth (Fig. S3). Therefore, we applied a $5 \%$ uncertainty to the water content measured in the laboratory to account for potential groundwatertable variability and long-term compaction of the deposit. The Supplement includes further details on the OSL dating protocol.

\subsubsection{Radiocarbon dating}

For radiocarbon dating we sliced peat samples into $1 \mathrm{~cm}$ segments, sieved them over a mesh of $500 \mu \mathrm{m}$ and used a microscope to select plant remains for AMS ${ }^{14} \mathrm{C}$ dating at the University of California, Irvine. If $1 \mathrm{~cm}$ did not contain sufficient material, the adjacent centimetre was searched (and so on) until enough material was gathered. The thickest dated interval is $4 \mathrm{~cm}$. For calibration to calendar years we used the IntCal13 curve (Reimer et al., 2013) and OxCal 4.1 (Bronk Ramsey, 2009). In order to facilitate comparison with the OSL ages, the radiocarbon ages are also reported in $\mathrm{ka} \pm 2 \sigma$ with respect to AD 2010 (Table 2). For the central age, the midpoint of the calibrated $2 \sigma$ range is used. Since calibrated age distributions are rarely normal, this central age may differ slightly from the weighted mean age. 


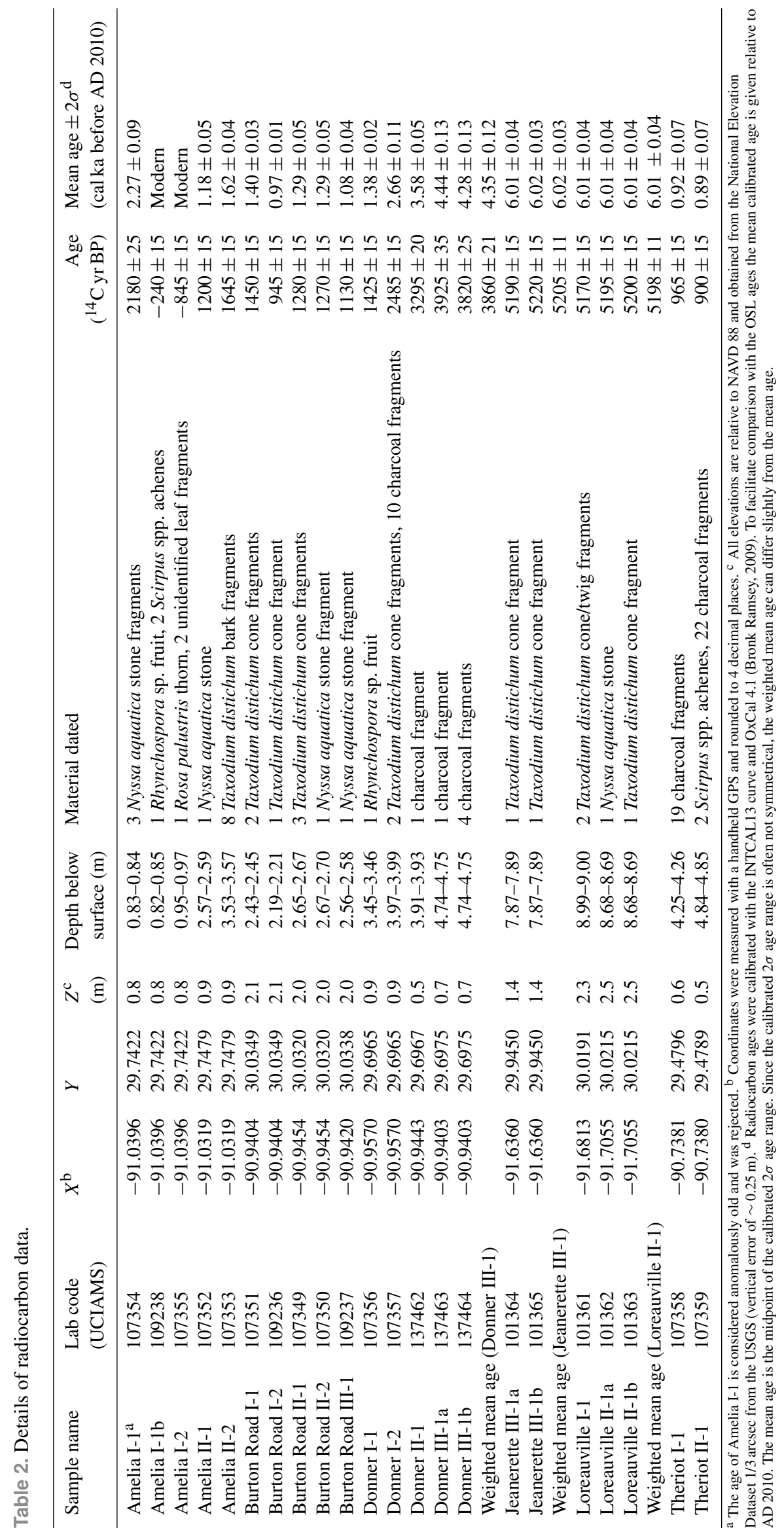




\section{New chronology for the Chenier Plain and Mississippi Delta plain}

\subsection{Chenier Plain}

All cross sections in the $\mathrm{CP}$ are oriented perpendicular to the chenier of interest. Internally, the cheniers mostly consist of very fine to fine sand with occasionally thick shell hash layers. The front of the chenier is relatively steep, while on the landward side the chenier thins out gradually. All OSL samples taken from the CP, except for sample Creole Ridge I-1, show overdispersion of $\sim 10 \%$, identical to the overdispersion of well-bleached samples from the MDP (Shen et al., 2015). $D_{\mathrm{e}}$ distributions show more than $90 \%$ of accepted aliquots that fall within the $2 \sigma$ range of the CAM $D_{\mathrm{e}}$ values (Fig. S2), suggesting that the chenier deposits were sufficiently bleached at deposition (cf. Shen and Lang, 2016). Therefore, a CAM was used (Table 1). Creole Ridge I-1 was rejected because it showed $\sim 20 \%$ overdispersion that is interpreted as due to post-depositional disturbance and the inclusion of younger grains. OSL ages from individual cheniers are generally in excellent agreement with each other. Some more specific details on the different cross sections are presented below, along with the new chronological data.

\subsubsection{Little Chenier}

Cross section Little Chenier East (LCE, Fig. 3a) shows a gently dipping Pleistocene substrate that is mostly capped by a palaeosol and a thin peat bed with ages of 4.0-3.7 ka (Yu et al., 2012). Little Chenier itself is a $2 \mathrm{~m}$ thick sandy deposit with a base around $-1 \mathrm{~m}$ NAVD. Its front and centre contain a prominent shell hash that mainly consists of oyster valves and fragments. The two OSL ages are nearly identical and indicate that this chenier formed $2.9 \pm 0.3 \mathrm{ka}$. Little Chenier West (LCW, Fig. 3b) exhibits similar dimensions and one age consistent with those from LCE. However, sample LCW V-1 has an age of $2.46 \pm 0.20 \mathrm{ka}$ that is regarded as anomalously young with respect to the three OSL ages of $\sim 2.9 \mathrm{ka}$ and it was therefore rejected.

\subsubsection{Chenier Perdue to Pumpkin Ridge}

Chenier Perdue has a deep base and an OSL age of $2.6 \pm$ $0.2 \mathrm{ka}$ (Figs. 3c, 4a). The next seaward chenier, Mura Ridge, is dated to $2.20 \pm 0.18 \mathrm{ka}$ (Fig. 4a). The most seaward chenier in this cross section, Pumpkin Ridge, is morphologically subdued but it can be traced over a considerable distance. It consists of silt loam or sandy loam with few shell fragments and is dated to $1.66 \pm 0.18 \mathrm{ka}$ (Fig. 4a). To the west these three cheniers merge into Creole Ridge (Fig. 2).

\subsubsection{Grand Chenier (Oak Grove Ridge)}

The Grand Chenier palaeo-shoreline (Fig. 4b) is the most prominent landform of the $\mathrm{CP}$. We dated the portion that

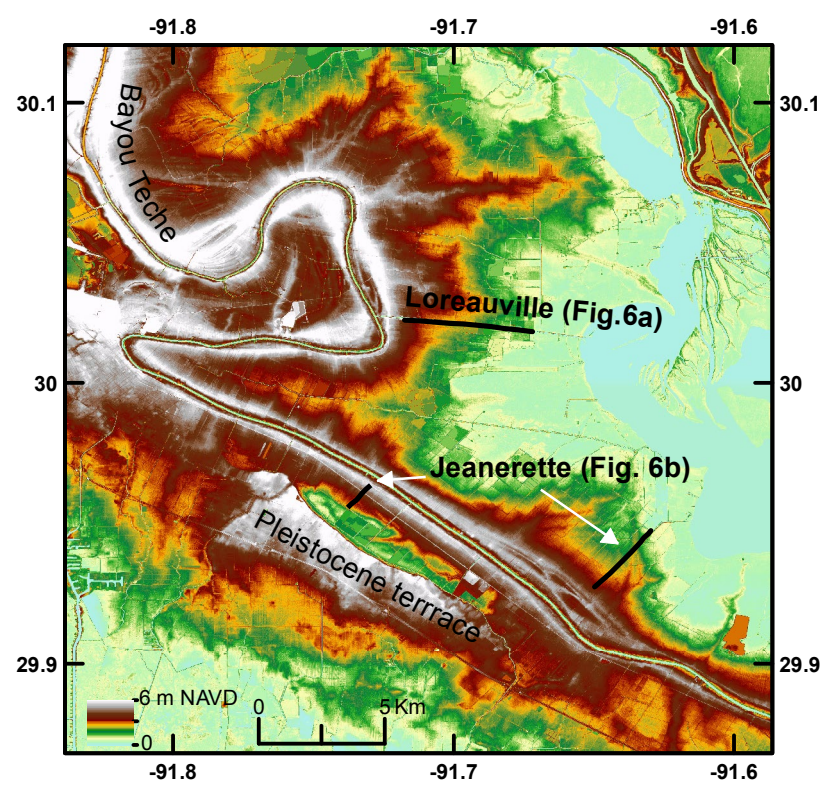

Figure 5. Digital elevation map (NED 1/3 arcsec) of the Bayou Teche system near New Iberia (for location see Fig. 1b) with the location of cross sections Loreauville and Jeanerette (Fig. 6).

is known as the Oak Grove Ridge; the back of the ridge is $1.29 \pm 0.10 \mathrm{ka}$ and the front is $1.19 \pm 0.12 \mathrm{ka}$. The base of the chenier is not always easy to pinpoint as it rests on a $2 \mathrm{~m}$ thick unit of sandy loam to very fine sand, similar grain sizes as found within the chenier itself. A notable change in relative density and a shift towards slightly darker-coloured material was used as a marker. The inferred thickness of Grand Chenier is in agreement with the work of Gremillion and Paine (1977), who studied the stratigraphy of Oak Grove Ridge in detail in three open pits.

\subsection{Mississippi Delta plain}

All cross sections in the MDP are oriented perpendicular to the main channel of interest. Some more specific details of the different cross sections are presented for each subdelta below, along with the new chronological data. The overdispersion values for OSL samples from the MDP commonly fall between 10 and $20 \%$, but can be significantly higher for samples younger than $1 \mathrm{ka}$ (Table 1; cf. Shen et al., 2015). For samples with an overdispersion value $<15 \%$, more than $90 \%$ of aliquots fall within the $2 \sigma$ band of the selected statistical age model (Fig. S2), suggesting that these samples are not affected by insufficient bleaching. A MAM and CAM often yield statistically identical ages. The samples with significantly larger overdispersion values are most likely affected by insufficient bleaching and a MAM is used in these cases. 
(a) Loreauville

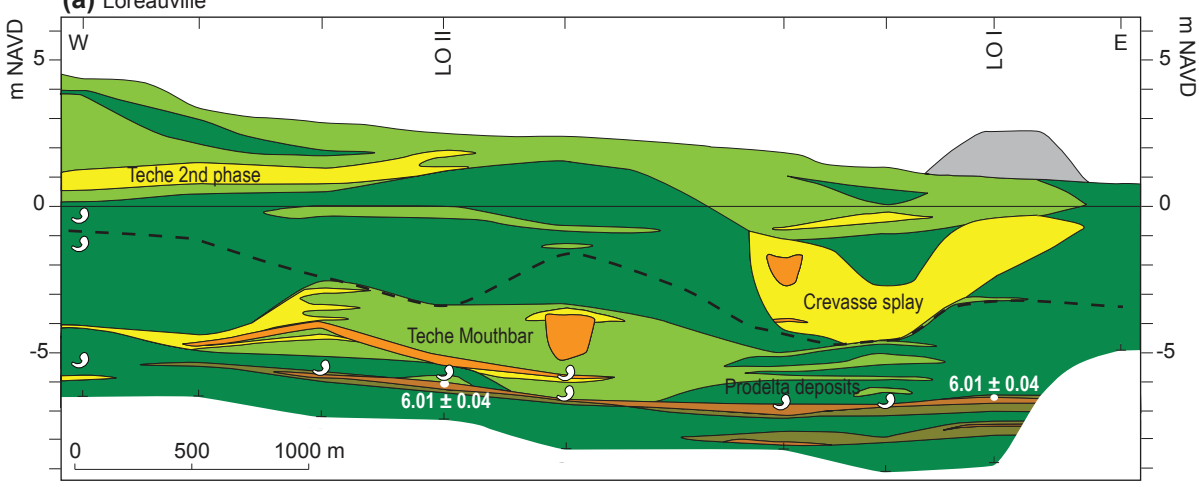

(b) Jeanerette
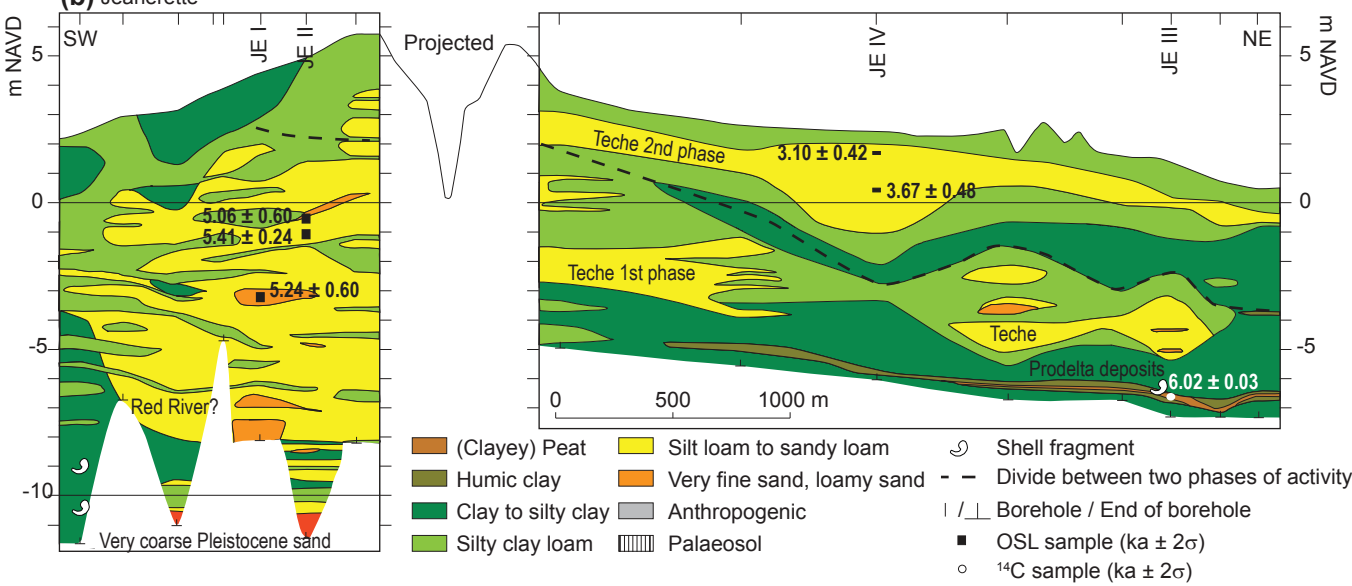

Figure 6. Cross sections (a) Loreauville and (b) Jeanerette with the stratigraphic position of the OSL (Table 1) and radiocarbon (Table 2) samples.

\subsubsection{Teche subdelta}

Cross sections Loreauville and Jeanerette (Figs. 5, 6) capture the Teche trunk channel just upstream of the Bayou Cypremort and Bayou Sale bifurcations (Fig. 1b). Both cross sections show a thin peat bed at a depth of $-6.5 \mathrm{~m}$ NAVD. The top of the peat bed was dated at three locations, yielding nearly identical ages $(\sim 6 \mathrm{ka}$, Table 2$)$. Directly above the peat, unidentified shell fragments are frequently encountered. The coarser sediment body above the peat bed in the Loreauville cross section (Fig. 6a) is interpreted as a mouth bar. It is therefore likely that the clay and shells below the mouth bar are part of prodelta deposits of the Teche subdelta that hence became active in the centuries after $6 \mathrm{ka}$. The occurrence of reddish clay layers directly above the peat indicate that a portion of the sediment load likely originated from the Red River. In both cross sections the stratigraphy east of Bayou Teche shows two stacked natural-levee deposits separated by flood-basin deposits, indicating two distinct phases of sedimentation. The upper deposits of the older phase are relatively firm due to pedogenesis. OSL samples from the deeper natural-levee deposits directly adjacent to Bayou Teche have ages of 5.4-5.1 ka. Two OSL samples from the upper half of the second phase show ages of $3.7-$ $3.1 \mathrm{ka}$. The uppermost sample was derived from a relatively shallow depth within the natural-levee deposits, suggesting that major sedimentation ended here around $3 \mathrm{ka}$.

Cross sections Donner and Amelia (Figs. 7, 8) still lie along the main channel belt of the Teche subdelta, but downstream of the Bayou Cypremort and Bayou Sale bifurcations (Fig. 1b). Below the peat layer at -2 to $-4 \mathrm{~m}$ NAVD, naturallevee and flood-basin deposits are present that can be directly linked to the Teche channel belt as they thicken towards it. We dated the base of the peat layer at four sites, but the results cover a wide age range. The youngest age $(1.62 \pm 0.04 \mathrm{ka})$ was obtained from site Amelia II, where the peat overlies a crevasse-splay deposit. The other samples were taken from peat resting on top of flood-basin deposits and show ages in the range $4.4-2.7 \mathrm{ka}$. This age discrepancy is partly explained by the relatively high position of the crevasse-splay deposit in the landscape and hence a lag in peat formation after the abandonment of the Teche subdelta. The large spread is not uncommon and likely reflects a diachronous onset of peat formation in the flood basin after channel abandonment (cf. Törnqvist and Van Dijk, 1993), whereby peat formation 


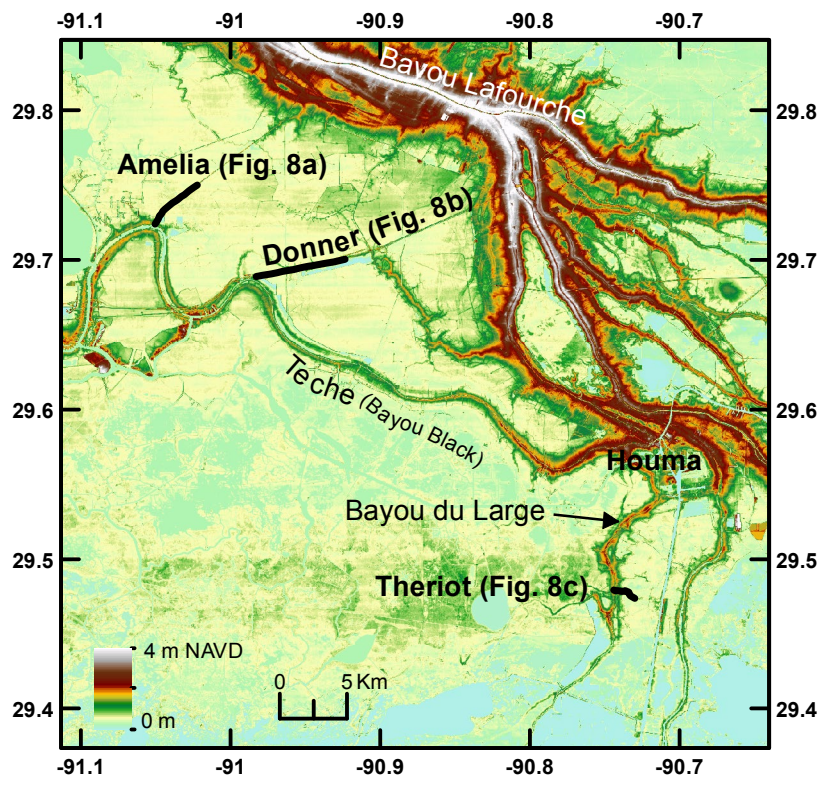

Figure 7. Digital elevation map (NED 1/3 arcsec) of Bayou Teche and Bayou du Large near Houma (for location see Fig. 1b) with the location of cross sections Amelia, Donner and Theriot (Fig. 8).

commences first in the lowest parts of the flood basin. In such a case, the older ages are more representative of the time of abandonment. The spread in ages could, however, also indicate a gradual abandonment of the Teche subdelta with less widespread sedimentation or a shift to more downstream sedimentation. It is clear though that sedimentation rates at Donner/Amelia have been very low after $\sim 3.6 \mathrm{ka}$ (sample Donner II-1), since the samples with younger ages (Donner I2 and Amelia II-2) lie only slightly higher. The top of the peat bed that covers Teche deposits was dated to 1.4-1.2 ka. It underlies flood-basin deposits that thin toward the Teche system, and hence we interpret them as originating from the Lafourche system to the east.

\subsubsection{St. Bernard and Plaquemines-Modern subdeltas}

Cross section Burton Road (Fig. 9) shows a peat bed at -4 to $-5 \mathrm{~m}$ NAVD (Fig. 10a) directly below St. Bernard deposits. Earlier work (Törnqvist et al., 1996) provided radiocarbon ages for the top of the peat bed in the direct vicinity of Burton Road, indicating that the St. Bernard subdelta became active shortly after $4 \mathrm{ka}$. In the flood basin, the St. Bernard deposits are capped by a peat layer of which the base was dated to 1.4-1.3 ka. In more proximal settings, closer to the channel, a palaeosol caps the natural levee. Two OSL samples from within the natural-levee deposits (Fig. 10) return ages of $\sim$ $2.5 \mathrm{ka}$ and these deposits are, hence, considerably older than the overlying peat bed, suggesting that major sedimentation ended well before peat formation started.
Further downstream, the St. Bernard trunk channel bifurcated into several smaller distributaries. We focused on Bayou Barataria (Fig. 11) as according to Saucier (1963) it was one of the last St. Bernard distributaries to be abandoned. The western portion of cross section Barataria (Fig. 12) shows natural-levee deposits of Bayou Barataria overlying a silty clay. The stiffness of the clay and the presence of iron oxides within the clay (while the base of the natural-levee deposits lacks iron oxides) indicate subaerial exposure and a time gap. The eastern part of the cross section traverses the inner bend of the channel and shows natural-levee and point-bar deposits. The three OSL ages indicate deposition between 2.6 and $2.0 \mathrm{ka}$.

The Plaquemines-Modern system reoccupied the St. Bernard channel (Saucier, 1963) and deposited sediments above the peat and the palaeosol at the Burton Road cross section (Fig. 10). Two new radiocarbon samples from the top of the peat bed give ages of $1.08 \pm 0.04$ and $0.97 \pm 0.01 \mathrm{ka}$, slightly younger than previously published ages. We assume that older ages of the top of this and correlative peat beds (Saucier, 1963; Törnqvist et al., 1996) may be more representative of the onset of the Plaquemines-Modern subdelta.

\subsubsection{Lafourche subdelta}

Along the trunk channel that fed the Lafourche subdelta extensive work has been done by Törnqvist et al. (1996) and Shen et al. (2015), showing that its period of activity occurred between 1.6 and $0.6 \mathrm{ka}$. We focused on the westernmost distributary of the Lafourche subdelta, Bayou du Large (cross section Theriot, Fig. 8c), as it lies closest to the CP. The stratigraphy is complex with a deep peat bed at $-10 \mathrm{~m}$ NAVD overlain by clayey prodelta or bay deposits containing shell hash. Close to the main channel of Bayou du Large this is followed by a natural-levee deposit, further away from the channel belt the deposits become more clayey and organic. The peat bed at -3 to $-4 \mathrm{~m}$ NAVD separates an older phase of fluvial activity from the most recent one. We dated the top of the peat bed at two sites to $0.9 \pm 0.1 \mathrm{ka}$, indicating the start of the last phase of activity of Bayou du Large. This is in agreement with an OSL age of $0.78 \pm 0.10 \mathrm{ka}$ above the peat. Below the peat bed, the fluvial deposits (Fig. 8c) formed most likely not too long after the Lafourche subdelta was initiated. Between -2 and $-3 \mathrm{~m}$ NAVD, reddish-coloured sediments indicate a connection between the Lafourche subdelta and the Red River.

\section{Palaeogeographic evolution}

\subsection{Chenier Plain}

Our data show that the Little Chenier palaeo-shoreline marks the halt of the Holocene transgression at $2.9 \pm 0.3 \mathrm{ka}$. A more landward Holocene shoreline can be excluded, in agreement 

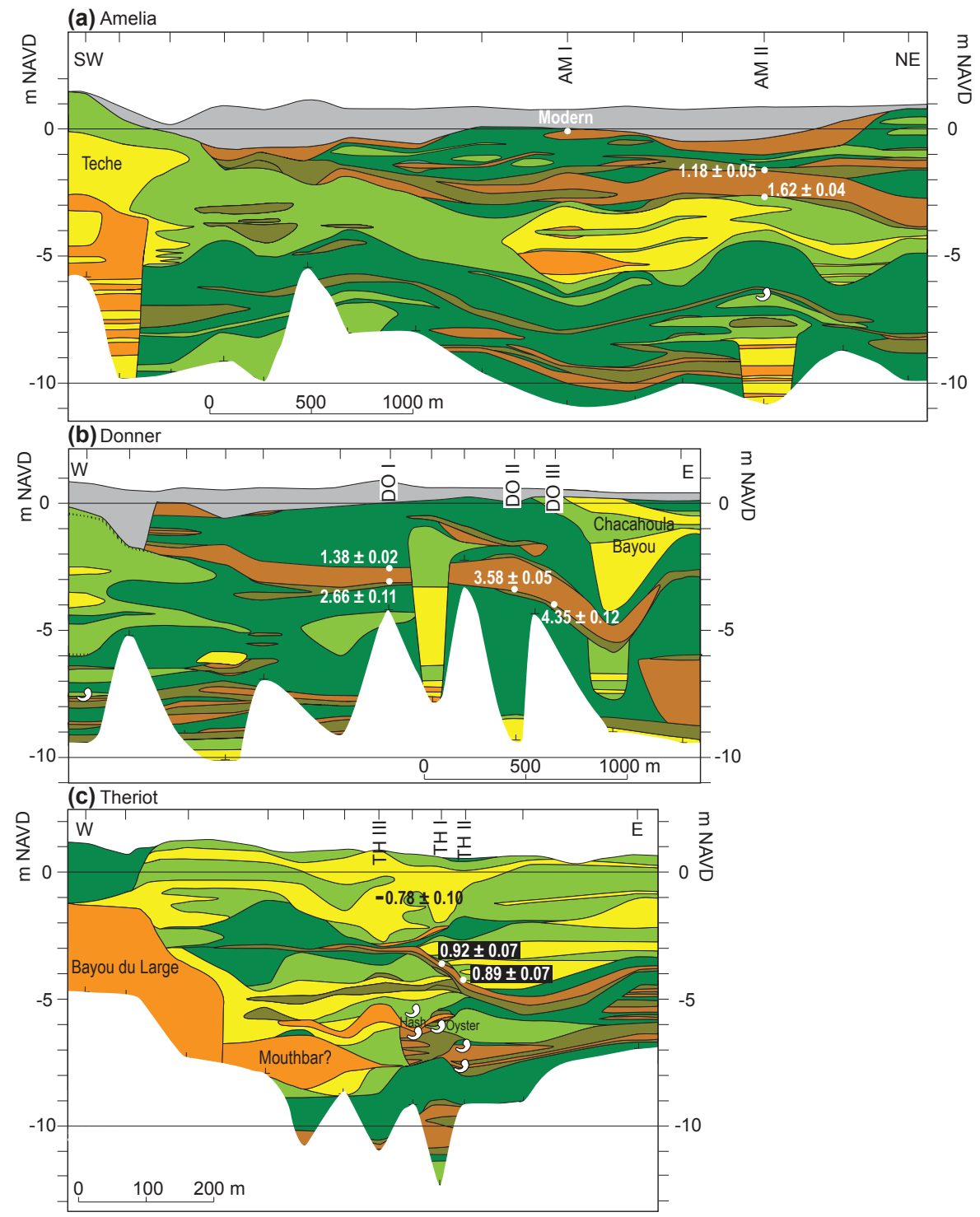

Figure 8. Cross sections (a) Amelia, (b) Donner and (c) Theriot with the stratigraphic position of the OSL (Table 1) and radiocarbon (Table 2) samples. See Fig. 6 for legend.

with the absence of shoreline features landward of Little Chenier (Penland and Suter, 1989). The OSL ages confirm that the CP formed during the past three millennia (Gould and McFarlan, 1959), but these new ages have significantly reduced the error margins for the ages of the individual palaeo-shorelines.

In order to compare $\mathrm{CP}$ evolution with changes in the MDP, we traced the major palaeo-shorelines between the Calcasieu River and Freshwater Bayou Canal near Vermillion Bay (Fig. 13, Table S2) using previous studies (Russell and Howe, 1935; Gould and McFarlan, 1959; Penland and Suter, 1989; McBride et al., 2007), digital elevation models (NED 1/3 arcsec; Gesch, 2007) and Google Earth. Except for the $0.5 \pm 0.3 \mathrm{ka}$ palaeo-shoreline (Table S2), the chronol- ogy is based entirely on the new OSL ages. South of White Lake the reconstructed shoreline positions are the most uncertain since the Grand Chenier palaeo-shoreline truncates many older palaeo-shoreline features in that area. In most cases a western and eastern segment of a truncated palaeoshoreline remains and we connected them using the simplest solution.

Using ArcMap we calculated the areas between the palaeo-shorelines and divided them by the elapsed time between chenier formation to obtain mass accumulation rates (Figs. 14, 15), accounting for age uncertainties. Using a constant $2 \mathrm{~m}$ thickness of the mudflat sediments (based on Gould and McFarlan, 1959) and a bulk density of $1500 \mathrm{~kg} \mathrm{~m}^{-3}$ we calculated rates in $\mathrm{Mtyr}^{-1}$. These are minimum rates as (1) it 


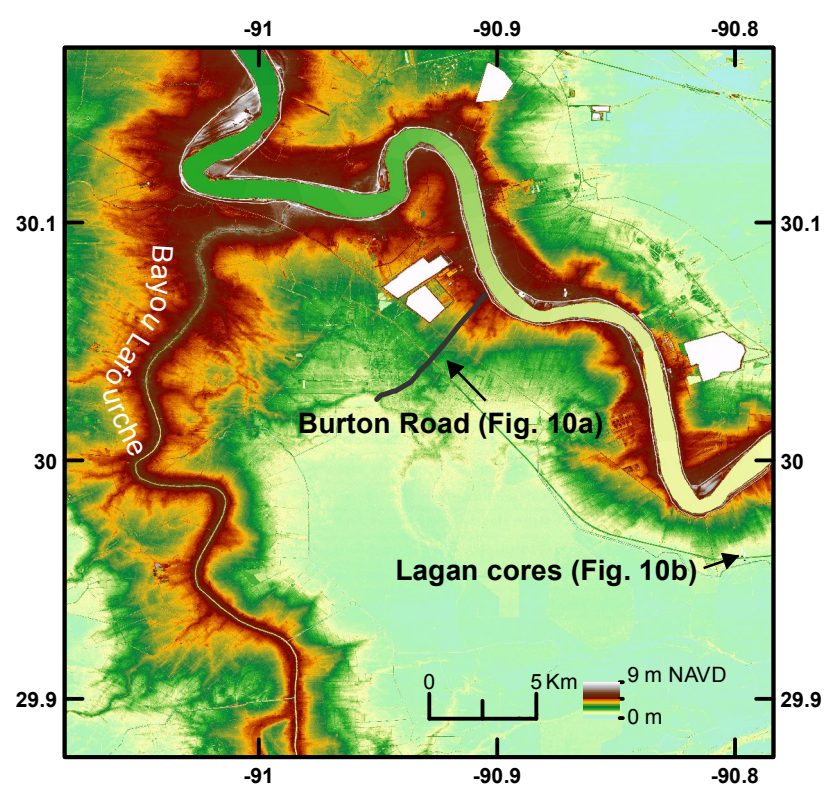

Figure 9. Digital elevation map (NED 1/3 arcsec) of the modern Mississippi River downstream of the Bayou Lafourche bifurcation (for location see Fig. 1b) with the location of cross section Burton Road and the Lagan cores (Fig. 10).

is unknown how much mudflat erosion may have occurred during chenier formation and (2) it is unknown for how long any given palaeo-shoreline remained stationary. If this occurred for a significant amount of time (decades or even centuries) the actual accumulation rates would be higher. Figure 14 shows that between 2.9 and $1.2 \mathrm{ka}$ mass accumulation rates for the entire $\mathrm{CP}$ were fairly constant, fluctuating between 0.5 and $1 \mathrm{Mtyr}^{-1}$. Between the formation of the $1.2 \pm 0.1 \mathrm{ka}$ and the $0.5 \pm 0.3 \mathrm{ka}$ palaeo-shorelines, mass accumulation rates were very high $\left(2.9 \pm 1.1 \mathrm{Mtyr}^{-1}, 2 \sigma\right.$ range $)$ and during that time about $66 \%$ of the current $\mathrm{CP}$ area was formed. During the past $0.5 \mathrm{ka}$ the mass accumulation rates for the $\mathrm{CP}$ were slightly negative on average. Local rivers (Calcasieu, Mermentau, Vermillion) transport a negligible $0.13 \mathrm{Mtyr}^{-1}$ (Rosen and $\mathrm{Xu}, 2011$ ) that is probably mostly trapped within the CP.

To study the evolution of different portions of the CP we calculated mass accumulation rates for four coastal segments (Fig. 15). The western (A) and central (B) segments are naturally divided by the Mermentau River. Segment $C$ is the area where a headland was present and segment $\mathrm{D}$ is the area east of the headland. All segments show overall growth until $\sim 0.5 \mathrm{ka}$, except for segment $\mathrm{C}$ that faced two periods of significant erosion. Interestingly, the highest rates of accumulation in segment A are not seen after $\sim 1.2 \mathrm{ka}$ as in the other sections, but rather between 1.6 and $1.2 \mathrm{ka}$. Erosion of the headland in segment $\mathrm{C}$ most likely constituted a significant sediment source to segment A during that time. Overall, the period between 2.5 and $1.6 \mathrm{ka}$ was very stable with relatively low accumulation rates and limited erosion of the headland. The shoreline of the $\mathrm{CP}$ was straightened considerably during the formation of the prominent Grand Chenier palaeo-shoreline around $1.2 \mathrm{ka}$.

\subsection{Mississippi Delta plain}

With the new data, the chronology of the Mississippi subdeltas and the palaeogeographic evolution of the MDP during the past $6 \mathrm{kyr}$ can be refined (Fig. 14). Activity of the Teche subdelta started sometime after $6 \mathrm{ka}$, the time that a peat bed of that age was buried by prodelta deposits (Fig. 6). Since by $5 \mathrm{ka}$ a thick natural-levee deposit had formed, it is unlikely that this subdelta was initiated after $5.5 \mathrm{ka}$ (Fig. 14), an interpretation that differs from previous work by Törnqvist et al. (2006). The two stacked natural levees alongside the Teche system (Fig. 6) bracket a period of limited activity that may have coincided with the onset of the St. Bernard subdelta shortly after $4 \mathrm{ka}$. The end of activity of the Teche subdelta remains ambiguous, but based on the new data major sedimentation in the study areas seems to have been very limited after 3.5-2.5 ka. This appears to match a period of erosion farther seaward, resulting in a regional ravinement surface (Penland et al., 1988). The prominence of the Teche channel belt on digital elevation maps, suggesting relatively recent activity, is tentatively linked to prolonged occupation of the Teche channel belt by the Red River. This river currently carries about $4 \%$ of the total Mississippi River discharge and formed a smaller pair of natural levees within the much wider alluvial ridge that was created during the peak of activity of the Teche subdelta (Gould and Morgan, 1962). Aslan et al. (2005) put abandonment of the Teche subdelta by the Red River somewhere between 2 and $1 \mathrm{ka}$, arguing that this was initiated by the progradation of the Lafourche subdelta across Teche distributaries. The Teche channel west of Houma (Fig. 8) was rejuvenated by a Lafourche channel (Gould and Morgan, 1962, and references therein), indicating complete abandonment of the Teche subdelta by that time. This reconstruction would imply that between $3.5-2.5 \mathrm{ka}$ and the initiation of the Lafourche subdelta, most of the Mississippi River discharge was directed to the St. Bernard subdelta.

The timing of the end of activity of the St. Bernard subdelta is more straightforward, although some uncertainties remain there as well. Along the trunk channel, the base of the peat bed overlying St. Bernard deposits was dated to $1.4-1.3 \mathrm{ka}$, while two OSL ages of sandy natural-levee deposits below the peat show ages of 2.6-2.5 ka. Downstream, along the Barataria distributary, OSL ages indicate activity until at least $2.0 \pm 0.2 \mathrm{ka}$. This is close to the initiation of the Lafourche subdelta around 1.7-1.5 ka (Törnqvist et al., 1996; Shen et al., 2015). Otvos and Giardino (2004) also report evidence for St. Bernard activity until at least $2 \mathrm{ka}$. Allowing for some time needed to form the peat bed and the palaeosol separating St. Bernard from Plaquemines-Modern deposits, 
(a) Burton Road

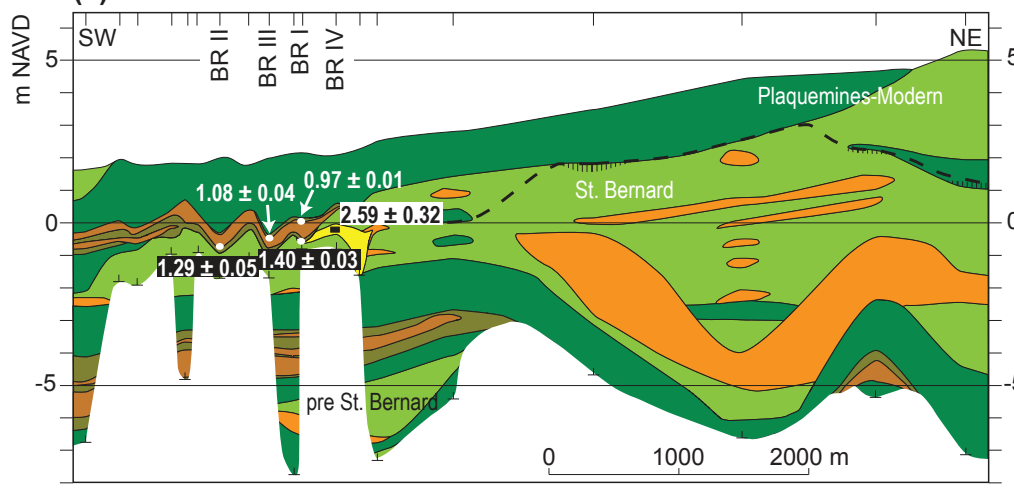

(b) Lagan

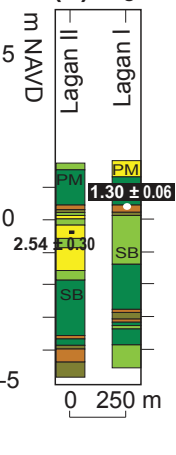

Figure 10. Cross section (a) Burton Road and two cores at (b) Lagan with the stratigraphic position of the OSL (Table 1) and radiocarbon (Table 2) samples. The radiocarbon age from Lagan I is from Törnqvist et al. (1996). See Fig. 6 for legend. PM: Plaquemines-Modern; SB: St. Bernard.

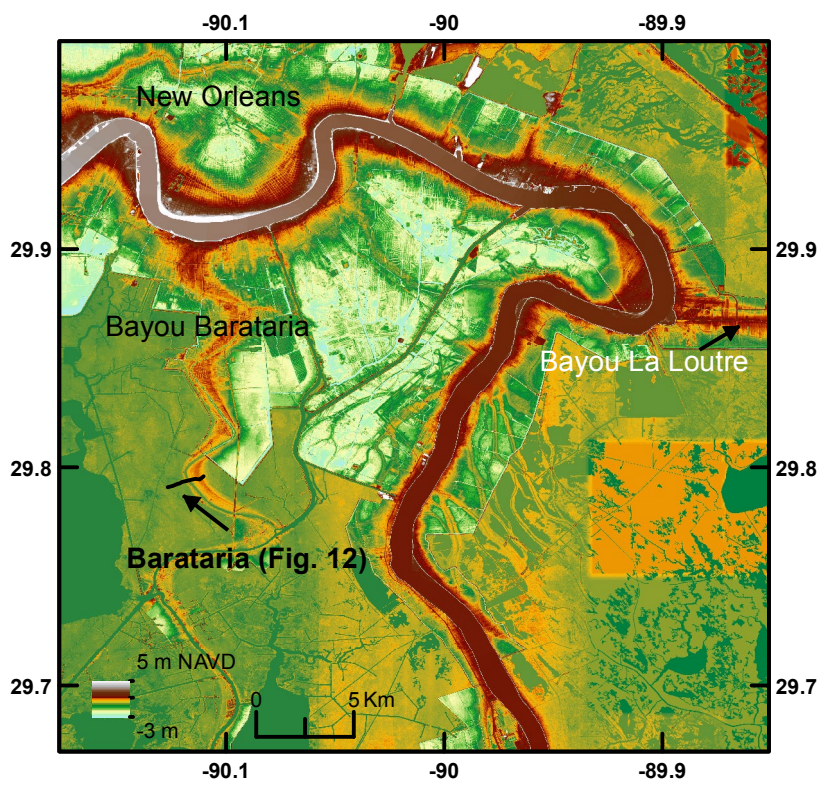

Figure 11. Digital elevation map (NED 1/3 arcsec) of the Barataria area (for location see Fig. 1b) with the location of cross section Barataria (Fig. 12).

we infer that the St. Bernard subdelta was abandoned before $1.7 \mathrm{ka}$. In this study, the top of the dividing peat bed was dated to $1.1-1.0 \mathrm{ka}$, only slightly younger than the $1.4-1.2 \mathrm{ka}$ age range reported by Törnqvist et al. (1996). This indicates that the Plaquemines-Modern subdelta was initiated between 1.4 and $1.0 \mathrm{ka}$. The end of Lafourche activity was recently dated to $0.6-0.5 \mathrm{ka}$ (Shen et al., 2015).

The most recently formed major distributary is the Atchafalaya River that is depicted as a relatively small channel on maps from the 16-18th centuries. It started as a crevasse channel of the Turnbull meander bend of the Mississippi River after this bend connected to the Red River (Fisk,

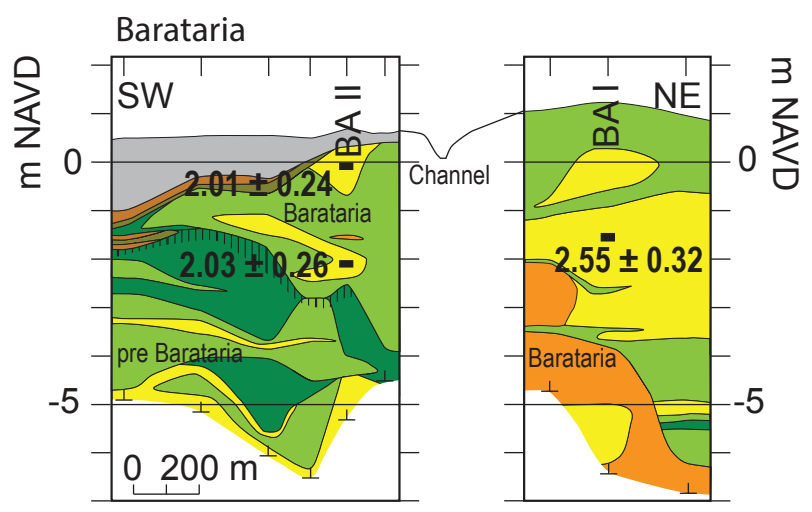

Figure 12. Cross section Barataria with the stratigraphic position of the OSL samples (Table 1). See Fig. 6 for legend.

1952; Aslan et al., 2005). The more detailed maps from the early 19th century indicate that the Atchafalaya system was still relatively small at the time (Holland, 2008). Fisk (1952) therefore postulated that only halfway through the 19th century the Atchafalaya River increased in size and started to form significant overbank deposits, aided by the clearance of a major $\log$ jam. This is in agreement with radiocarbon ages of plant material at the base of Atchafalaya overbank strata that fall in the range of $0.20-0.15 \mathrm{ka}$, with plant material below these deposits dated to $0.6-0.2 \mathrm{ka}$ (Weinstein and Wells, 2004). In the Atchafalaya Bay, the Wax Lake delta (WLD) started to form in the early 1940s after the artificial creation of an additional outlet for the Atchafalaya River. Bay deposits directly below the prodelta deposits of the WLD yielded an OSL age of 0.35-0.30 ka (Shen and Mauz, 2012), suggesting little sedimentation in the bay in the centuries before the start of the WLD and in agreement with a relatively small Atchafalaya River. Based on the above it is likely 


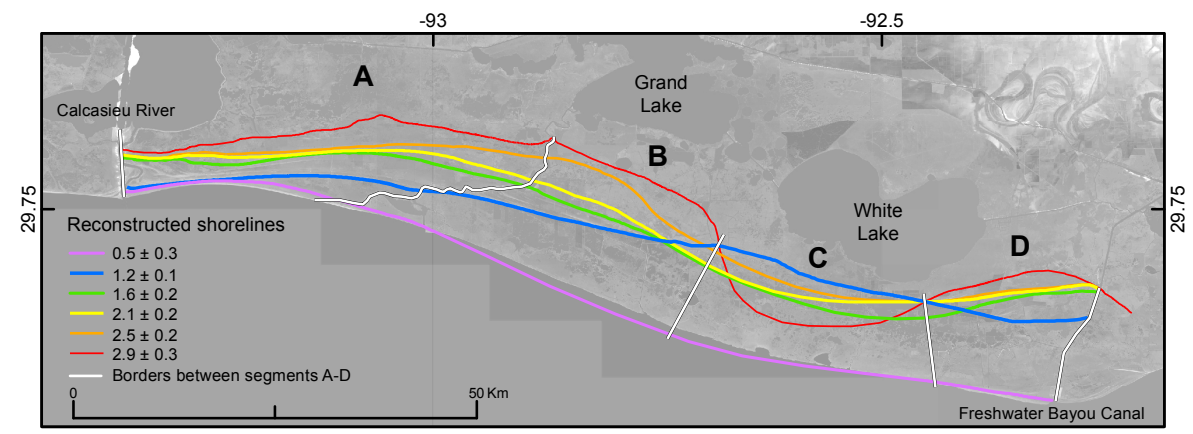

Figure 13. Six palaeo-shorelines reconstructed from the Chenier Plain, along with the location of coastal segments A-D. See Table S2 for background information on the chronology.

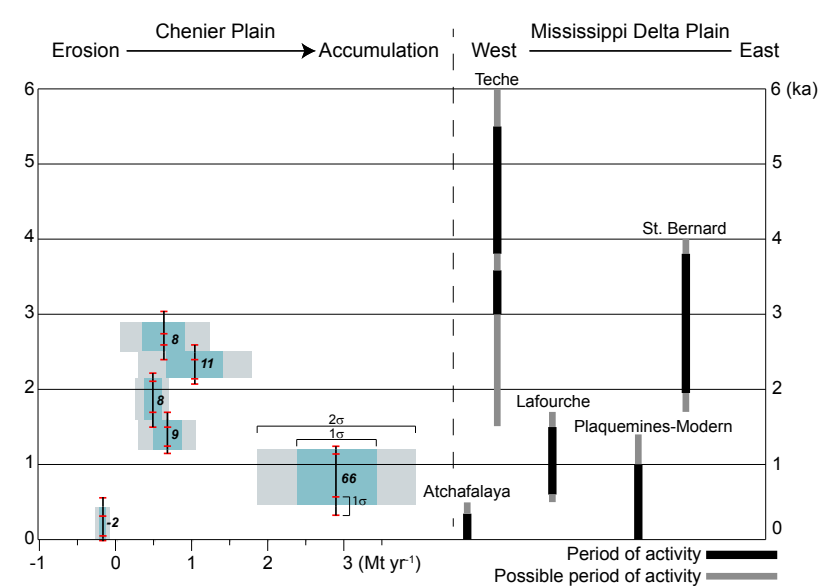

Figure 14. Accumulation patterns for the Chenier Plain with the chronology and the relative position of subdeltas in the Mississippi Delta plain during the past $6 \mathrm{kyr}$. The numbers next to the vertical error bar of the accumulation rates show the relative contribution to the total accumulation for each period of accumulation. The vertical error bars are derived from the inferred ages in Table S2, while the horizontal error bars account for the uncertainty in the accumulation rate due to age uncertainties.

that a significant sediment contribution to the longshore current from the Atchafalaya River did not start before halfway through the 19th century.

\section{Discussion}

\subsection{Implications for relative sea-level reconstruction from cheniers}

Cheniers are erosive geomorphological features that typically form immediately on top of marsh or tidal-flat deposits. The relationship of the elevation of chenier deposits with sea level is not necessarily uniform. For example, Augustinus (1980) describes two types of cheniers along the shoreline of Surinam: medium to coarse sandy cheniers with a base at the mean high-tide level and fine sandy cheniers with a
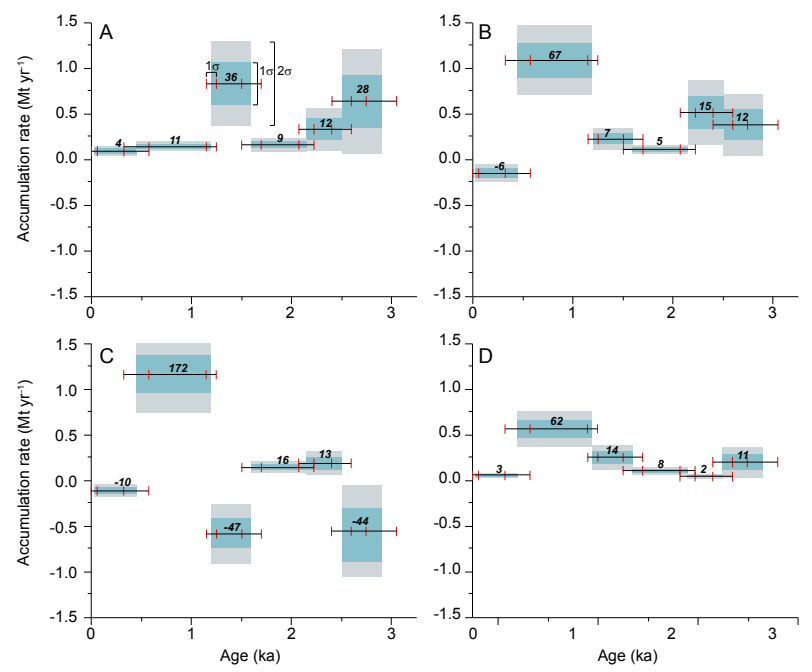

Figure 15. Mass accumulation rates for coastal segments A-D in the Chenier Plain (Fig. 13). Since the segments have different sizes, the relative contribution (in \%, plotted above the horizontal error bar) of each time interval to the total accumulation was calculated to facilitate comparison.

base at the mean low-tide level. Anthony (1989) puts the base of cheniers in Sierra Leone between mean sea level and mean spring high tide. Studies from China indicate a base of cheniers near the mean high-tide level (Yan et al., 1989; Ying and Xiankun, 1989), while Horne et al. (2015) show cheniers in Australia with a base $0.1-0.2 \mathrm{~m}$ above the mean spring low-tide level. On the other hand, Dougherty and Dickson (2012) use the contact between chenier beach sand and foreshore deposits as a sea-level indicator. In addition, crest elevations of cheniers have been used as a sea-level indicator (McBride et al., 2007). This is problematic though, since their heights may be related to storm-induced wave setup (Yan et al., 1989; Otvos, 2005) and hence their relationship with sea level is not straightforward. Still, McBride et al. (2007) used average crest heights of cheniers in the CP 
to reconstruct past sea level, using the average crest height of modern cheniers $(\sim 1.2 \mathrm{~m}$ NAVD) as an indicator for the relationship between crest heights and sea level. Since the average crest heights of the cheniers along the Little and Grand Chenier palaeo-shoreline are $\sim 2.5$ and $\sim 3 \mathrm{~m}$ NAVD, respectively, they argued for a higher than present sea level during the formation of these palaeo-shorelines. However, using high-resolution sea-level indicators from compaction-free intertidal facies, Yu et al. (2012) showed that RSL was at about $-1.5 \mathrm{~m}$ NAVD around $3 \mathrm{ka}$, i.e. during the formation of Little Chenier. This demonstrates that chenier crest heights are not suitable as sea-level indicators.

The cheniers in the CP have undulating bases (Figs. 3, 4) due to spatially variable erosion patterns; hence chenier bases are problematic sea-level indicators. However, overwash deposits represented by relatively thin sand sheets with a relatively flat base occur landward of the cheniers. Since these deposits formed directly on the pre-existing marsh or tidal flat, we consider the base of these overwash deposits the most suitable sea-level indicator. The surface elevation of the marsh behind the modern chenier is $\sim 0.5 \mathrm{~m}$ NAVD on average, just below the highest astronomical tide level for this area. We obtained upper limiting data points from the base of overwash deposits using the protocol outlined in Hijma et al. (2015, Table S4). In other words, we assume that mean sea level occurred below the base of any given overwash deposit during its formation. To minimize the influence of compaction we used the elevation of the base of the thinner, more landward parts of the overwash deposits. Since the depth to the consolidated substrate below the overwash deposits increases seaward from $1.5 \mathrm{~m}$ (Little Chenier) to almost $5 \mathrm{~m}$ (Grand Chenier), the amount of compaction likely increases seaward as well. Considering that the overwash deposit under consideration are about $0.5 \mathrm{~m}$ thick and the depth to the consolidated substrate is less than $5 \mathrm{~m}$, the amount of associated compaction is likely on the order of decimetres only.

The new data fill the gap that existed in the Holocene RSL synthesis for the CP and MDP (Yu et al., 2012) and show that sea level remained below present mean sea level in the CP during the late Holocene (Fig. 16) (even taking into account compaction), consistent with recent findings from south Texas by Livsey and Simms (2013). The limiting data points exhibit the same rising trend as seen in the existing CP and MDP RSL records, except for the youngest limiting data point from Grand Chenier, which falls slightly below this trend. This may be explained by more compaction due to thicker chenier and overwash deposits and a relatively large depth to the consolidated Pleistocene substrate. More focused research that includes observations from modern analogues as well as direct OSL dating of overwash deposits is needed to further improve our insight on the relationship between the elevation of overwash deposits and sea level. Such research could potentially make overwash deposits associated with cheniers suitable to obtain sea-level index points, both in our study area and elsewhere in the world.

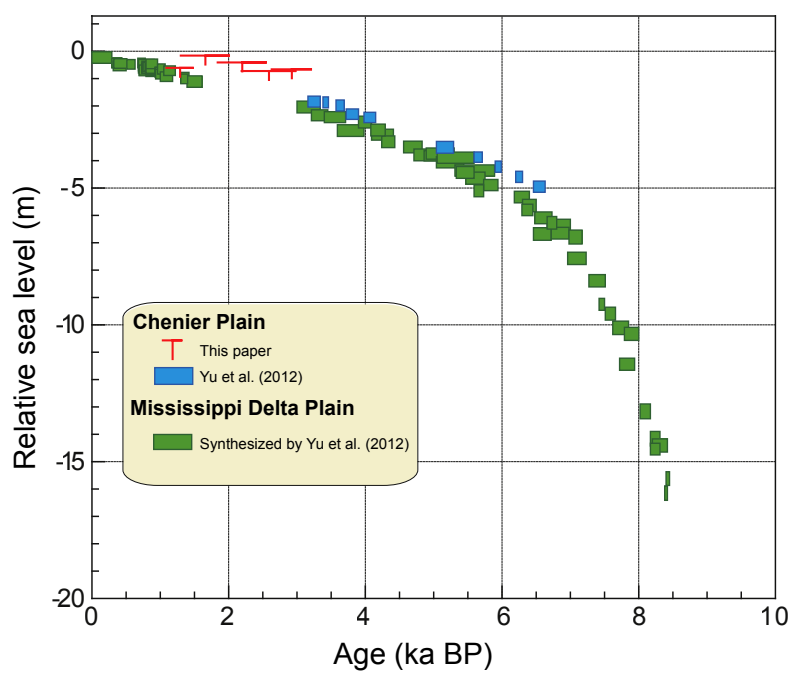

Figure 16. Comparison of Holocene relative sea-level records derived from cheniers (this study) and basal peat from the Chenier Plain and the Mississippi Delta plain (Yu et al., 2012). The chenieroverwash data are interpreted as upper limiting data (see text). For the limiting data, the width of the horizontal bar is defined by the $2 \sigma$ age error and the length of the vertical bar by its $2 \sigma$ error range (Table S4).

\subsection{Coupled Mississippi Delta plain-Chenier Plain evolution}

Figure 14 shows that the progradation history of the $\mathrm{CP}$ is dominated by one major episode, namely the period between 1.2 and $0.5 \mathrm{ka}$, when a westward thinning wedge of sediment accumulated that forms $66 \%$ of the current CP area. The thinning pattern is distinct, exemplified by relatively low accumulation rates in the most westward segment (Fig. 15), pointing towards a sediment source east of the CP, i.e. the MDP. Since the timing of this episode corresponds closely with the period of activity of the Lafourche subdelta, we hold the shift from the St. Bernard to the Lafourche subdelta responsible for this period of rapid progradation. Prior to this period, progradation rates were rather constant, while after this period the $\mathrm{CP}$ was relatively stable with increased erosion in recent times, likely due to recent accelerated sealevel rise and sediment starvation. We agree with McBride et al. (2007) that, especially near the CP river mouths, local effects resulted in deviations from this general picture of $\mathrm{CP}$ evolution, resulting in spits and curved beach ridges.

The individual evolution of the four segments, however, also shows marked differences that require further explanation. An important feature during CP evolution was the headland south of White Lake that is linked to the buried deposits of the Lafayette meander belt of the ancestral Mississippi River (Fig. 1a). This headland was especially prominent between 2.9 and $2.5 \mathrm{ka}$, but remained in place until the palaeoshoreline was straightened around $1.2 \mathrm{ka}$. West of the head- 
land a bay was present, bounded to the west by the Calcasieu River mouth (Fig. 13). We argue that the infill of this bay was to a large extent fed by headland erosion and the resulting abundant sediment. This is illustrated by the match of two distinct phases of headland erosion with two equally distinct phases of accumulation in segment A. During the first phase the eroded volume near the headland constituted $\sim 90 \%$ of the accumulated volume in segment $\mathrm{A}$ and during the second phase it was $\sim 70 \%$. We rule out the possibility that the infill of the bay was dominated by sediment from contemporary Mississippi subdeltas as accumulation rates in segment D, closest to the MDP, were not particularly high and much lower than during the period of Lafourche activity. Building upon the notion that segment $\mathrm{D}$ is the most sensitive to changes in the position of the main Mississippi River mouth and accepting that the Lafourche subdelta sediment output was responsible for overall rapid progradation between 1.2 and $0.5 \mathrm{ka}$, we argue that between $2.9 \mathrm{ka}$ and the initiation of the Lafourche subdelta (1.7-1.5 ka) the locus of Mississippi sediment output was east of the Lafourche subdelta. In other words, during roughly the first half of $\mathrm{CP}$ evolution, the St. Bernard subdelta carried most of the discharge (Fig. 14). If the Teche subdelta was still active to a significant extent, this should have resulted in more rapid accumulation rates than what is recorded, especially since the Teche subdelta lies closer to the $\mathrm{CP}$ than the Lafourche subdelta.

The question that then arises is what caused CP progradation to start around $2.9 \mathrm{ka}$. Fisk (1948) and Penland and Suter (1989) hypothesized that this was due to Teche and Lafourche activity, respectively, which is untenable in view of the new chronological data. Gould and McFarlan (1959) linked the change to the initiation of Bayou Barataria, the most western distributary of the St. Bernard subdelta. Our new data indicate that Bayou Barataria was indeed active during that time and could have contributed sediment to the longshore current. In addition to this, the strong erosion of the Teche subdelta promontory (Penland et al., 1987) most likely occurred during this timeframe as well and would have formed a substantial sediment source. However, these two sediment sources cannot explain the shift from overall transgression to overall progradation around $2.9 \mathrm{ka}$, since the close proximity of the Teche subdelta and its activity in the millennia before $2.9 \mathrm{ka}$ would have resulted in an equally or most likely even larger sediment source. We therefore argue that the shift to overall progradation was triggered by a gradual slowdown in the rate of RSL rise (Fig. 16) in combination with abundant local sediment supply from the eroding headland, possibly augmented by the eroding Teche subdelta. The $\sim 1.5 \mathrm{~m}$ rise of RSL during the past $3 \mathrm{kyr}$ (Fig. 16) was driven by regional subsidence, mainly due to glacial isostatic adjustment (Yu et al., 2012). Sea-level oscillations on the order of a few decimetres have been proposed for this time period (González and Törnqvist, 2009) and may have had an, at this point undetermined, impact on $\mathrm{CP}$ evolution.
The above explains the start of the $\mathrm{CP}$ formation around $2.9 \mathrm{ka}$ and the period of rapid accumulation after $1.2 \mathrm{ka}$, but several issues remain. The first concerns the $\sim 20 \mathrm{~km}$ westward drift of the mouth of the Mermentau River during the past $1.6 \mathrm{kyr}$. We tentatively link this to the final infill of the bay of the Mermentau River. Around $2.5 \mathrm{ka}$ the palaeoshoreline reconstruction (Fig. 13) still shows the presence of a bay, while the $1.6 \mathrm{ka}$ palaeo-shoreline is much straighter. This would have resulted in a stronger influence of the longshore current on river-mouth morphology and the formation of spits that forced the river mouth to shift westward. This was aided by abundant sediment supply from the eroding headland between 1.6 and $1.3 \mathrm{ka}$, as well as the Lafourche subdelta. A second issue concerns the formation of the very prominent and wide Grand Chenier palaeo-shoreline that straightened the shoreline of the $\mathrm{CP}$, hereby causing renewed erosion of the headland that had been rather stable for nearly 1 kyr. Our OSL ages indicate that Grand Chenier formation started around $1.3 \mathrm{ka}$ and lasted for at least a century (Fig. 4b). Its large width, in comparison to the other cheniers, and the fact that the OSL ages decrease in a seaward direction are indicative of progradation. Both Penland and Suter (1989) and McBride et al. (2007) linked the formation of the Grand Chenier palaeo-shoreline to changes within the Lafourche subdelta, hence suggesting that the main river mouth of the subdelta shifted east. At present, this cannot be substantiated with chronological data from the Lafourche subdelta. In addition, McBride et al. (2007) suggested RSL rise as an important factor in the formation of the Grand Chenier palaeo-shoreline. Data from González and Törnqvist (2009) indeed suggest relatively high rates of RSL rise between 1.2 and $0.8 \mathrm{ka}$, within the range of Grand Chenier formation. Figure 14 allows for a third explanation, namely that the formation of the Grand Chenier palaeo-shoreline is linked to the initiation of the Plaquemines-Modern subdelta.

\subsection{Implications for coastal restoration}

Within Louisiana's Coastal Master Plan (CPRA, 2017) to battle land loss due to RSL rise and sediment deficits, USD 5 billion has been dedicated to sediment diversions. The intent is to lose less sediment to the Gulf of Mexico and instead use this material to create new land within the MDP. This is also the focus of ChangingCourse.us, an independent initiative that has solicited plans to restore the natural landbuilding capacity of the river while maintaining the navigation system. The potential of creating new land using Mississippi River sediment was demonstrated during the 2011 flood (Allison et al., 2012; Falcini et al., 2012; Nittrouer et al., 2012). In some of the plans, sediment of the Atchafalaya River is diverted to the Terrebonne Bay area, while further east diversions have been proposed to Barataria Bay and Breton Sound (Fig. 1). The current focus lies on these two latter locations (CPRA, 2017). 
It can be expected that due to diversions the delivery of Mississippi River sediment to the longshore current will change. However, most of the sediment will initially be trapped within MDP bays and hence will not reach the CP. This is currently also the case for the Atchafalaya River, of which only $0.5 \%$ of the transported $70 \mathrm{Mtyr}^{-1}$ reaches the CP (Draut et al., 2005b), although this is still sufficient to cause progradation in the eastern CP. This percentage is strikingly similar to what we have reconstructed for the active phase of the Lafourche subdelta when $2.9 \pm 1.1 \mathrm{Mt} \mathrm{yr}^{-1}$ accumulated in the CP. Assuming that the Mississippi River had a sediment load somewhere between 200 and $400 \mathrm{Mt} \mathrm{yr}^{-1}$, about $0.5-1.5 \%$ of the sediment ended up in the CP during that time interval. This indicates that the planned diversions have the potential to also result in a slowdown of $\mathrm{CP}$ erosion, especially after some of the MDP bays have been filled in. In summary, our results show that if only $0.5-1.5 \%$ of the total Mississippi River sediment load would reach the CP, erosion might be expected to decrease considerably, although this effect may well be outpaced by the projected increase in the rate of RSL rise.

The MDP is not the only delta plain that is currently losing land due to a combination of high rates of RSL rise and underutilization of the potentially available sediment. Especially in Asia this is a prominent problem in muddominated systems, such as the Huanghe and Mekong deltas (e.g. Schmidt, 2015; Day et al., 2016). Our study shows that changes in sediment management in such deltas are likely to have impacts that may extend well beyond the delta plain, affecting adjacent coastal plains with dense populations and high economic value.

\section{Conclusions}

This study shows that the evolution of the Mississippi Delta plain (MDP) and the adjacent Chenier Plain (CP) is interlinked. Based on OSL and radiocarbon dating we conclude that the CP started to form around $3 \mathrm{ka}$. Large-scale patterns in the evolution of the $\mathrm{CP}$ are a direct consequence of shifting subdeltas, in addition to changes in regional sediment sources and rates of RSL change. We obtained new limiting sea-level data from overwash deposits associated with the cheniers, showing that RSL rose steadily during the past $3 \mathrm{kyr}$. Contrary to what has been suggested before, sea level never reached an elevation higher than present. We argue that the base of the overwash deposits has the potential to become a useful sea-level indicator, in the $\mathrm{CP}$ as well as in comparable settings elsewhere in the world.

The period with the highest accumulation rates in the $\mathrm{CP}$ $(1.2-0.5 \mathrm{ka})$ is directly linked to a westward shift of the Mississippi River, resulting in abundant sediment supply. The $2.9 \pm 1.1 \mathrm{Mt}$ that accumulated each year in the $\mathrm{CP}$ during this period corresponds to $0.5-1.5 \%$ of the total sediment load of the present-day Mississippi River. Remarkably, roughly the same percentage of the Atchafalaya sediment load is currently reaching the $\mathrm{CP}$ and resulting in local shoreline progradation. This suggests that sediment diversions focused on the central or western portions of the MDP may lead to a slowdown of erosion, not just locally but also along the shoreline of the CP. A marked difference with the present and future, however, is that the $\mathrm{CP}$ evolved under conditions of relatively slow rates of RSL rise. It therefore remains to be seen whether the $\mathrm{CP}$ can survive the currently ongoing acceleration of sea-level rise, even if sediment supply increases.

Information on the interlinked CP-MDP evolution from the present study, combined with data on the large-scale evolution of other large delta systems, should be used to constrain future generations of numerical models to obtain more robust predictions of the effects of improved sediment management and accelerated rates of relative sea-level rise on the evolution of mud-dominated coastal environments worldwide.

Data availability. All newly collected borehole data are archived at Tulane University and will be publicly released, as part of a larger database, at a later time. They are currently still being used within the context of other, ongoing projects.

\section{The Supplement related to this article is available online at https://doi.org/10.5194/esurf-5-689-2017-supplement.}

Author contributions. MPH and TET designed the project. MPH led all the fieldwork and prepared the radiocarbon samples. ZS was involved in fieldwork and, together with BM, prepared, dated and analysed all OSL samples. MPH composed the manuscript with input from ZS and TET. All figures, except for Fig. 15 (ZS), were created by MPH.

Competing interests. The authors declare that they have no conflict of interest.

Acknowledgements. We would like to thank Jennifer Kuykendall, Arielle Woods, Elizabeth Chamberlain, Krista Jankowski and Jon Marshak for field assistance. Arielle Woods also assisted with reconstructing chenier palaeo-shorelines. We acknowledge all the landowners for allowing us to drill on their land. We are grateful to the Rockefeller Wildlife Refuge for their hospitality during our stay in the Chenier Plain. The fieldwork along Bayou Barataria was possible due to the kind assistance of Julie Whitbeck of the National Park Service, who allowed us to drill in the Barataria Preserve of the Jean Lafitte Natural Historic Park and Preserve. Lee Newsom (Penn State) helped with identifying macrofossils for radiocarbon dating. Funding was provided by the US Department of Energy through the National Institute for Climatic Change 
Research Coastal Center. This is a contribution to the PALSEA programme.

Edited by: Richard Gloaguen

Reviewed by: Amy East, Jennifer Miselis, and Adam D. Switzer

\section{References}

Adamiec, G. and Aitken, M. J.: Dose-rate conversion factors: update, Ancient TL, 16, 37-50, 1998.

Aitken, M. J.: An introduction to optical dating. The dating of Quaternary sediments by the use of photon-stimulated luminescence, Oxford University Press, Oxford, 1998.

Allison, M. A. and Meselhe, E. A.: The use of large water and sediment diversions in the lower Mississippi River (Louisiana) for coastal restoration, J. Hydrol., 387, 346-360, https://doi.org/10.1016/j.jhydrol.2010.04.001, 2010.

Allison, M. A., Demas, C. R., Ebersole, B. A., Kleiss, B. A., Little, C. D., Meselhe, E. A., Powell, N. J., Pratt, T. C., and Vosburg, B. M.: A water and sediment budget for the lower Mississippi-Atchafalaya River in flood years 20082010: Implications for sediment discharge to the oceans and coastal restoration in Louisiana, J. Hydrol., 432-433, 84-97, https://doi.org/10.1016/j.jhydrol.2012.02.020, 2012.

Anthony, E. J.: Chenier plain development in northern Sierra Leone, West Africa, Mar. Geol., 90, 297-309, https://doi.org/10.1016/0025-3227(89)90132-1, 1989.

Anthony, E. J., Gardel, A., Proisy, C., Fromard, F., Gensac, E., Peron, C., Walcker, R., and Lesourd, S.: The role of fluvial sediment supply and river-mouth hydrology in the dynamics of the muddy, Amazon-dominated Amapá-Guianas coast, South America: A three-point research agenda, J. S. Am. Earth Sci., 44, 18 24, https://doi.org/10.1016/j.jsames.2012.06.005, 2013.

Arnold, L. J., Bailey, R. M., and Tucker, G. E.: Statistical treatment of fluvial dose distributions from southern Colorado arroyo deposits, Quat. Geochronol., 2, 162-167, https://doi.org/10.1016/j.quageo.2006.05.003, 2007.

Aslan, A., Autin, W. J., and Blum, M. D.: Causes of River Avulsion: Insights from the Late Holocene Avulsion History of the Mississippi River, U.S.A., J. Sediment. Res., 75, 650-664, 2005.

Augustinus, P. G. E. F.: Actual development of the chenier coast of Suriname (South America), Sediment. Geol., 26, 91-113, 1980.

Augustinus, P. G. E. F.: Cheniers and chenier plains: A general introduction, Mar. Geol., 90, 219-229, https://doi.org/10.1016/0025-3227(89)90126-6, 1989.

Autin, W. J., Burns, S. F., Miller, B. J., Saucier, R. T., and Snead, J. I.: Quaternary geology of the lower Mississippi Valley, in: Quaternary nonglacial geology: Conterminous US, edited by: Morrison, R. B., The Geological Society of America, 547-582, 1991.

Blum, M. D. and Roberts, H. H.: Drowning of the Mississippi Delta due to insufficient sediment supply and global sea-level rise, Nature Geosci., 2, 488-491, 2009.

Blum, M. D. and Roberts, H. H.: The Mississippi Delta region: past, present, and future, Annu. Rev. Earth Pl. Sc., 40, 655-683, https://doi.org/10.1146/annurev-earth-042711-105248, 2012.

Bronk Ramsey, C.: Bayesian Analysis of Radiocarbon Dates, Radiocarbon, 51, 337-360, 2009.
Byrne, J. V., LeRoy, D. O., and Riley, C. M.: The chenier plain and its stratigraphy, southwestern Louisiana, Gulf Coast Association Geological Society T., IX, 237-260, 1959.

Coleman, J. M., Roberts, H. H., and Stone, G. W.: Mississippi River Delta: An Overview, J. Coastal Res., 14, 699-716, 1998.

Couvillion, B. R., Beck, H., Schoolmaster, D., and Fischer, M. M.: Land area change in coastal Louisiana (1932 to 2016), U.S. Geological Survey Scientific Investigations Map 3381, U.S. Geological Survey, Reston, VA, 16 p., 2017.

CPRA: Louisiana's comprehensive master plan for a sustainable coast, Coastal Protection and Restoration Authority of Louisiana, Baton Rouge, Louisiana, 171 p., 2017.

Day, J. W., Boesch, D. F., Clairain, E. J., Kemp, G. P., Laska, S. B., Mitsch, W. J., Orth, K., Mashriqui, H., Reed, D. J., Shabman, L., Simenstad, C. A., Streever, B. J., Twilley, R. R., Watson, C. C., Wells, J. T., and Whigham, D. F.: Restoration of the Mississippi Delta: Lessons from Hurricanes Katrina and Rita, Science, 315, 1679-1684, 2007.

Day, J. W., Agboola, J., Chen, Z., D’Elia, C., Forbes, D. L., Giosan, L., Kemp, P., Kuenzer, C., Lane, R. R., Ramachandran, R., Syvitski, J., and Yañez-Arancibia, A.: Approaches to defining deltaic sustainability in the 21 st century, Estuar. Coast. Shelf S., 183, 275-291, https://doi.org/10.1016/j.ecss.2016.06.018, 2016.

Dougherty, A. J. and Dickson, M. E.: Sea level and storm control on the evolution of a chenier plain, Firth of Thames, New Zealand, Mar. Geol., 307-310, 58-72, https://doi.org/10.1016/j.margeo.2012.03.003, 2012.

Draut, A. E., Kineke, G. C., Huh, O. K., Grymes III, J. M., Westphal, K. A., and Moeller, C. C.: Coastal mudflat accretion under energetic conditions, Louisiana chenier-plain coast, USA, Mar. Geol., 214, 27-47, https://doi.org/10.1016/j.margeo.2004.10.033, 2005 a.

Draut, A. E., Kineke, G. C., Velasco, D. W., Allison, M. A., and Prime, R. J.: Influence of the Atchafalaya River on recent evolution of the chenier-plain inner continental shelf, northern Gulf of Mexico, Cont. Shelf Res., 25, 91-112, https://doi.org/10.1016/j.csr.2004.09.002, 2005b.

Ericson, J. P., Vörösmarty, C. J., Dingman, S. L., Ward, L. G., and Meybeck, M.: Effective sea-level rise and deltas: Causes of change and human dimension implications, Global Planet. Change, 50, 63-82, https://doi.org/10.1016/j.gloplacha.2005.07.004, 2006.

Falcini, F., Khan, N. S., Macelloni, L., Horton, B. P., Lutken, C. B., McKee, K. L., Santoleri, R., Colella, S., Li, C., Volpe, G., D'Emidio, M., Salusti, A., and Jerolmack, D. J.: Linking the historic 2011 Mississippi River flood to coastal wetland sedimentation, Nature Geosci., 5, 803-807, 2012.

Fisk, H. N.: Geological investigations of the alluvial valley of the lower Mississippi River, Army Corps of Engineers, Mississippi River Commission, Vicksburg, USA, 1944.

Fisk, H. N.: Geological investigation of the lower Mermentau River Basin and adjacent areas in coastal Louisiana, Mississippi River Commission, U.S. Army Corps of Engineers, Vicksburg, USA, 40 p., 1948.

Fisk, H. N.: Geological investigation of the Atchafalaya Basin and the problem of Mississippi River diversion, Mississippi River Commission, U.S. Army Corps of Engineers, Vicksburg, USA, 138 p., 1952. 
Fisk, H. N., Kolb, C. R., McFarlan, E., and Wilbert, L. J.: Sedimentary framework of the modern Mississippi delta [Louisiana], J. Sediment. Petrol., 24, 76-99, 1954.

Frazier, D. E.: Recent deltaic deposits of the Mississippi River, their development and chronology, Gulf Coast Association of Geological Societies T., 17, 287-315, 1967.

Galbraith, R. F., Roberts, R. G., Laslett, G. M., Yoshida, H., and Olley, J. M.: Optical dating of single and multiple grains of quartz from Jinmium rock shelter, northern Australia: Part I. Experimental design and statistical models, Archaeometry, 41, 339364, https://doi.org/10.1111/j.1475-4754.1999.tb00987.x, 1999.

Gesch, D.: The National Elevation Dataset, in: Digital Elevation Model Technologies and Applications: The DEM User Manual, 2nd edition, edited by: Maune, D., American Society for Photogrammetry and Remote Sensing, Bethesda, Maryland, USA, 99-118, 2007.

González, J. L. and Törnqvist, T. E.: A new Late Holocene sealevel record from the Mississippi Delta: evidence for a climate/sea level connection?, Quaternary Sci. Rev., 28, 17371749, https://doi.org/10.1016/j.quascirev.2009.04.003, 2009.

Gould, H. R. and McFarlan, E.: Geologic history of the Chenier Plain, southwestern Louisiana, Gulf Coast Association of Geological Societies T., 9, 261-270, 1959.

Gould, H. R. and Morgan, J. P.: Coastal Louisiana Swamps and Marshlands: Field Trip No. 9, HGS Special Volumes, 287-341, 1962.

Gremillion, R. P. and Paine, W. R.: The internal structure of Oak Grove Ridge Chenier, Gulf Coast Association of Geological Societies T., 27, 278-282, 1977.

Heinrich, P. V.: Pleistocene and Holocene fluvial systems of the Lower Pearl River, Mississippi and Louisiana, Gulf Coast Association of Geological Societies T., 56, 267-278, 2006.

Hijma, M. P., Engelhart, S. E., Horton, B. P., Törnqvist, T. E., Hu, P., and Hill, D. F.: A protocol for a geological sea-level database, in: Handbook of Sea-Level Research, edited by: Shennan, I., Long, A. J., and Horton, B. P., Wiley Blackwell, 536-553, 2015.

Hill, D. F., Griffiths, S. D., Peltier, W. R., Horton, B. P., and Törnqvist, T. E.: High-resolution numerical modeling of tides in the western Atlantic, Gulf of Mexico, and Caribbean Sea during the Holocene, J. Geophys. Res., 116, C10014, https://doi.org/10.1029/2010JC006896, 2011.

Holland, R. A.: The Mississippi River in Maps \& Views: From Lake Itasca to The Gulf of Mexico, Rizzoli, New York, 2008.

Horne, D., Lees, B., Cupper, M., and Fitzsimmons, K.: The development of the Princess Charlotte Bay chenier plain: New results and insights, Mar. Geol., 364, 12-20, https://doi.org/10.1016/j.margeo.2015.03.004, 2015.

Howe, H. V., Russell, R. J., McGuirt, J. H., Craft, B. C., and Stevenson, M. B.: Reports on the geology of Cameron and Vermilion parishes: Louisiana, Geol. Surv. B., 6, 242-242, 1935.

Livsey, D. and Simms, A. R.: Holocene sea-level change derived from microbial mats, Geology, 41, 971-974, https://doi.org/10.1130/g34387.1, 2013.

LSU: Atlas: The Louisiana Statewide GIS, LSU Department of Geography and Anthropology, Baton Rouge, LA, available at: http://atlas.lsu.edu (last access: August 2012), 2011.

Mauz, B., Bode, T., Mainz, E., Blanchard, H., Hilger, W., Dikau, R., and Zöller, L.: The luminescence dating laboratory at the Univer- sity of Bonn: equipment and procedures, Ancient TL, 20, 53-61, 2002.

McBride, R. A., Taylor, M. J., and Byrnes, M. R.: Coastal morphodynamics and Chenier-Plain evolution in southwestern Louisiana, USA: A geomorphic model, Geomorphology, 88, 367-422, https://doi.org/10.1016/j.geomorph.2006.11.013, 2007.

McFarlan, E.: Radiocarbon dating of Late Quaternary deposits, south Louisiana, Geol. Soc. Am. Bull., 72, 129-158, 1961.

McGranahan, G., Balk, D., and Anderson, B.: The rising tide: assessing the risks of climate change and human settlements in low elevation coastal zones, Environ. Urban., 19, 17-37, https://doi.org/10.1177/0956247807076960, 2007.

Meade, R. H. and Moody, J. A.: Causes for the decline of suspended-sediment discharge in the Mississippi River system, 1940-2007, Hydrol. Process., 24, 35-49, https://doi.org/10.1002/hyp.7477, 2010.

Nittrouer, J. A., Best, J. L., Brantley, C., Cash, R. W., Czapiga, M., Kumar, P., and Parker, G.: Mitigating land loss in coastal Louisiana by controlled diversion of Mississippi River sand, Nature Geosci., 5, 534-537, https://doi.org/10.1038/ngeo1525, 2012.

Olley, J. M., Murray, A., and Roberts, R. G.: The effects of disequilibria in the uranium and thorium decay chains on burial dose rates in fluvial sediments, Quat. Geochronol., 15, 751-760, 1996.

Otvos, E. G.: Beach ridges - definitions and significance, Geomorphology, 32, 83-108, 2000.

Otvos, E. G.: Coastal barriers, Gulf of Mexico: Holocene evolution and chronology, J. Coastal Res., 21, 141-163, 2005.

Otvos, E. G. and Giardino, M. J.: Interlinked barrier chain and delta lobe development, northern Gulf of Mexico, Sediment. Geol., 169, 47-73, https://doi.org/10.1016/j.sedgeo.2004.04.008, 2004.

Otvos, E. G. and Price, W. A.: Problems of chenier genesis and terminology - An overview, Mar. Geol., 31, 251-263, 1979.

Paola, C., Twilley, R. R., Edmonds, D. A., Kim, W., Mohrig, D., Parker, G., Viparelli, E., and Voller, V. R.: Natural Processes in Delta Restoration: Application to the Mississippi Delta, Annu. Rev. Mar. Sci., 3, 67-91, 2011.

Penland, S. and Suter, J. R.: The geomorphology of the Mississippi River chenier plain, Mar. Geol., 90, 231-258, https://doi.org/10.1016/0025-3227(89)90127-8, 1989.

Penland, S., Suter, J. R., and McBride, R. A.: Delta Plain development and sea level history in the Terrebonne coastal region, Louisiana, in: Coastal Sediments '87, edited by: Kraus, N. C., American Society of Civil Engineers, New York, 1689-1705, 1987.

Penland, S., Boyd, R., and Suter, J. R.: Transgressive depositional systems of the Mississippi Delta plain; a model for barrier shoreline and shelf sand development, J. Sediment. Petrol., 58, 932949, 1988.

Prescott, J. R. and Hutton, J. T.: Cosmic ray contributions to dose rates for luminescence and ESR dating: Large depths and long-term time variations, Radiat. Meas., 23, 497-500, https://doi.org/10.1016/1350-4487(94)90086-8, 1994.

Reimer, P. J., Bard, E., Bayliss, A., Beck, J. W., Blackwell, P. G., Bronk Ramsey, C., Buck, C. E., Edwards, R. L., Friedrich, M., Grootes, P. M., Guilderson, T. P., Haflidason, H., Hajdas, I., Hatté, H., Heaton, T. J., Hoffmann, D. L., Hogg, A. G., Hughen, K. A., Kaiser, K. F., Kromer, B., Manning, S. W., Niu, M., 
Reimer, R. W., Richards, D. A., Scott, J. R., Southon, J. R., Turney, C. S. M., and Van der Plicht, J.: IntCal13 and Marine13 radiocarbon age calibration curves $0-50,000 \mathrm{yr}$ cal BP, Radiocarbon, 55, 1869-1887, 2013.

Rhodes, E. J.: Optically Stimulated Luminescence Dating of Sediments over the Past 200,000 Years, Annu. Rev. Earth Pl. Sc., 39, 461-488, 2011.

Roberts, H. H. and Coleman, J. M.: Holocene evolution of the deltaic plain: a perspective - from Fisk to present, Eng. Geol., 45, 113-138, https://doi.org/10.1016/s0013-7952(96)00010-5, 1996.

Roberts, H. H., Huh, O. K., Hsu, S. A., Rouse Jr., L. J., and Rickman, D. A.: Winter storm impacts on the chenier plain coast of southwestern Louisiana. Gulf Coast Association of Geological Societies T., 39, 515-522, 1989.

Rosen, T. and Xu, Y. J.: Riverine sediment inflow to Louisiana Chenier Plain in the Northern Gulf of Mexico, Estuar. Coast. Shelf S., 95, 279-288, https://doi.org/10.1016/j.ecss.2011.09.013, 2011.

Russell, R. J.: Quaternary history of Louisiana, Geol. Soc. Am. Bull., 51, 1199-1233, https://doi.org/10.1130/gsab-511199, 1940.

Russell, R. J. and Howe, H. V.: Cheniers of Southwestern Louisiana, Geogr. Rev., 25, 449-461, 1935.

Saito, Y., Wei, H., Zhou, Y., Nishimura, A., Sato, Y., and Yokota, S.: Delta progradation and chenier formation in the Huanghe (Yellow River) delta, China, J. Asian Earth Sci., 18, 489-497, https://doi.org/10.1016/S1367-9120(99)00080-2, 2000.

Saucier, R. T.: Recent geomorphic history of the Pontchartrain Basin, Louisiana State University Press, Baton Rouge, USA, 1963.

Schmidt, C.: Alarm over a sinking delta, Science, 348, 845-846, https://doi.org/10.1126/science.348.6237.845, 2015.

Shang, Z., Wang, F., Li, J., Marshall, W. A., Chen, Y., Jiang, X., Tian, L., and Wang, H.: New residence times of the Holocene reworked shells on the west coast of Bohai Bay, China, J. Asian Earth Sci., 115, 492-506, https://doi.org/10.1016/j.jseaes.2015.10.008, 2016.

Shen, Z. and Lang, A.: Quartz fast component opticallystimulated luminescence: Towards routine extraction for dating applications, Radiat. Meas., 89, 27-34, https://doi.org/10.1016/j.radmeas.2016.01.034, 2016.

Shen, Z. and Mauz, B.: Optical dating of young deltaic deposits on a decadal time scale, Quat. Geochronol., 10, 110-116, https://doi.org/10.1016/j.quageo.2012.01.014, 2012.

Shen, Z., Törnqvist, T. E., Autin, W. J., Mateo, Z. R. P., Straub, K. M., and Mauz, B.: Rapid and widespread response of the Lower Mississippi River to eustatic forcing during the last glacial-interglacial cycle, Geol. Soc. Am. Bull., 124, 690-704, https://doi.org/10.1130/b30449.1, 2012.

Shen, Z., Törnqvist, T. E., Mauz, B., Chamberlain, E. L., Nijhuis, A. G., and Sandoval, L.: Episodic overbank deposition as a dominant mechanism of floodplain and delta-plain aggradation, Geology, 43, 875-878, https://doi.org/10.1130/g36847.1, 2015.
Shen, Z., Dawers, N. H., Törnqvist, T. E., Gasparini, N. M., Hijma, M. P., and Mauz, B.: Mechanisms of late Quaternary fault throwrate variability along the north central Gulf of Mexico coast: implications for coastal subsidence, Basin Res., 29, 557-570, https://doi.org/10.1111/bre.12184, 2017.

Syvitski, J. P. M., Kettner, A. J., Correggiari, A., and Nelson, B. W.: Distributary channels and their impact on sediment dispersal, Mar. Geol., 222-223, 75-94, 2005.

Szczuciński, W., Jagodziński, R., Hanebuth, T. J. J., Stattegger, K., Wetzel, A., Mitręga, M., Unverricht, D., and Van Phach, P.: Modern sedimentation and sediment dispersal pattern on the continental shelf off the Mekong River delta, South China Sea, Global Planet. Change, 110, Part B, 195-213, https://doi.org/10.1016/j.gloplacha.2013.08.019, 2013.

Törnqvist, T. E. and Van Dijk, G. J.: Optimizing sampling strategy for radiocarbon dating of Holocene fluvial systems in a vertically aggrading setting, Boreas, 22, 129-145, https://doi.org/10.1111/j.1502-3885.1993.tb00172.x, 1993.

Törnqvist, T. E., Kidder, T. R., Autin, W. J., Van den Borg, K., De Jong, A. F. M., Klerks, C. J. W., Snijders, E. M. A., Storms, J. E. A., Van Dam, R. L., and Wiemann, M. C.: A revised chronology for Mississippi River subdeltas, Science, 273, 1693-1696, 1996.

Törnqvist, T. E., Bick, S. J., Van der Borg, K., and De Jong, A. F. M.: How stable is the Mississippi Delta?, Geology, 34, 697-700, 2006.

Weinstein, R. A. and Wells, D. C.: Cultural resources investigation of the public access lands in the Atchafalaya basin floodway, Indian Bayou north project area, St. Landry Parish, Louisiana, Draft Report, Coastal Environments, Inc. for US Army Corps of Engineers, Baton Rouge, Louisiana, 2004.

Wong, P. P., Losada, I. J., Gattuso, J.-P., Hinkel, J., Khattabi, A., McInnes, K. L., Saito, Y., and Sallenger, A.: Coastal systems and low-lying areas, Climate Change 2014: Impacts, Adaptation, and Vulnerability. Part A: Global and Sectoral Aspects, Contribution of Working Group II to the Fifth Assessment Report of the Intergovernmental Panel on Climate Change Cambridge University Press, Cambridge, UK/New York, USA, 361-409, 2014.

Yan, Q., Xu, S., and Shao, X.: Holocene cheniers in the Yangtze Delta, China, Mar. Geol., 90, 337-343, https://doi.org/10.1016/0025-3227(89)90135-7, 1989.

Ying, W. and Xiankun, K.: Cheniers on the east coastal plain of China, Mar. Geol., 90, 321-335, https://doi.org/10.1016/00253227(89)90134-5, 1989.

Yu, S.-Y., Törnqvist, T. E., and Hu, P.: Quantifying Holocene lithospheric subsidence rates underneath the Mississippi Delta, Earth Planet. Sci. Lett., 331-332, 21-30, https://doi.org/10.1016/j.epsl.2012.02.021, 2012. 